\title{
Gesamtverzeichnis der Publikationen aus MONICA/KORA Augsburg 1984 bis Anfang 2005
}

\section{Total List of Publications of MONICA/KORA Augsburg 1984 until the Beginning of 2005}

\section{MONICA/KORA-Studiengruppe *}

${ }^{1}$ Aparicio ML, Döring A, Mielck A, Holle R. Unterschiede zwischen Aussiedlern und der übrigen deutschen Bevölkerung bezüglich $\mathrm{Ge}-$ sundheit, Gesundheitsversorgung und Gesundheitsverhalten - Eine vergleichende Analyse anhand des KORA-Surveys 2000. Soz Praventivmed 2005; 50 (2): 107-18

${ }^{2}$ Baessler A, Hasinoff MJ, Fischer M, Reinhard W, Sonnenberg GE, Olivier M, Erdmann J, Schunkert H, Doering A, Jacob HJ, Cumuzzie AG, Kissebah AH, Kwitek AE. Genetic linkage and association of the growth hormone secretagogue receptor (GHSR, ghrelin receptor) gene in human obesity. Diabetes 2005; 54 (1): 259-267

${ }^{3}$ Dobson AJ, Barnett AG, for the WHO MONICA Project. Estimating trends and seasonality in coronary heart disease. Stat Med 2004; 23: 3503-3523

${ }^{4}$ Barnett AG, Dobson AJ, for the WHO MONICA Project. Is the increase in coronary heart disease on Mondays an artifact of registration? Epidemiology 2004; 15: $583-588$

${ }^{5}$ Barnett AG, Dobson AJ, McElduff P, Salomaa V, Kuulasmaa K, Sans S, for the WHO MONICA Project. Cold periods and coronary events: an analysis of populations worldwide. J Epidemiol Community Health 2005; 59: $551-557$

${ }^{6}$ Barth W, Löwel H, Lewis M, Classen E, Herman B, Quietzsch D, Greiser E, Keil U, Heinemann L, Voigt G, Brasche S, Böthig S. Coronary heart disease mortality, morbidity, and case fatality in five East and West German cities 1985 - 1989. J Clin Epidemiol 1996; 49: 1277-1284

${ }^{7}$ Bäßler A, Hengstenberg C, Holmer S, Fischer M, Mayer B, Hubauer U, Klein G, Riegger G, Schunkert H. Long-term effects of in-hospital cardiac rehabilitation on the cardiac risk profile: a case control study in pairs of siblings with myocardial infarction. Eur Heart J 2001; 22: $1111-1118$

${ }^{8}$ Baumann A, Filipiak B, Stieber J, Löwel H. Familienstand und soziale Integration als Prädiktoren der Mortalität: eine 5-Jahres-Follow-upStudie an 55- bis 74jährigen Männern und Frauen in der Region Augsburg. Z Gerontol Geriatr 1998; 31: 184-192

9 Baumann A, Stieber J, Löwel H. Nichtteilnahme als Einflußfaktor auf die Aussagefähigkeit von Follow-up-Studien. Gesundheitswesen 1997; 59 (Sonderheft 1): 19-25
${ }^{10}$ Baumert J, Ladwig KH, Döring A, Löwel H, Wichmann HE, für die MONICA/KORA-Studiengruppe. Zeitliche Veränderungen und Einflussfaktoren des Rauchverhaltens im Hinblick auf die Umsetzung von Präventionsmaßnahmen. Gesundheitswesen 2005; 67 S1: S46 - S50

${ }^{11}$ Berger K, Hense HW, Rothdach A, Weltermann B, Keil U. A single question about prior stroke versus a stroke questionnaire to assess stroke prevalence in populations. Neuroepidemiology 2000; 19: $245-257$

12 Berger K, Kolominsky-Rabas P, Heuschmann P, Keil U. Die Häufigkeit des Schlaganfalls in Deutschland - Prävalenzen, Inzidenzen und ihre Datenquellen. Dtsch Med Wochenschr 2000; 125: 21 - 25

${ }^{13}$ Berger K, Roesler A, Kretzschmar K. The association between white matter lesions, stroke and activities of daily living - The MEMO Study on the KORA Platform Augsburg. Gesundheitswesen 2005; 67 S1: S172-S175

${ }^{14}$ Berger K, von Eckardstein A, Trenkwalder C, Rothdach A, Junker R, Weiland SK. Iron metabolism and the risk of Restless-Legs-Syndrome in an elderly, general population - The MEMO-Study. J Neurol 2002; 249: 1195 - 1199

15 Berger K. Die Epidemiologie des Schmerzes. In: Grahlow I, Husstedt I, Bothe, Evers S, Hürter, Schilgen (Hrsg). Spezielle Schmerztherapie. Stuttgart/New York: F. K. Schattauer Verlagsgesellschaft, 2001

${ }^{16}$ Berger K. Epidemiologie zerebrovaskulärer Erkrankungen. In: Hartmann A, Heiß WD (Hrsg). Der Schlaganfall - Pathogenese, Klinik, Diagnostik und Therapie zerebrovaskulärer Erkrankungen. Darmstadt: Steinkopff Verlag, 2001: $123-150$

17 Berger K. Epidemiologie. In: Grotemeyer KH (Hrsg). Diagnose, Differentialdiagnose, Therapie und Rehabilitation des Hirninfarktes. Bremen: UNI-MED-Verlag, 2000: $18-21$

${ }^{18}$ Böhler E, Schäfer T, Ruhdorfer S, Weigl L, Wessner D, Heinrich J, Filipiak B, Wichmann HE, Ring J. Epidemiologie von Nahrungsmittel-Allergien im Erwachsenenalter. Allergo J 2001; 10: 318 - 319

19 Braune BT, Berger K. The influence of depressive mood on activities of daily living and health care utilization in the elderly - The MEMO study on the KORA Platform Augsburg. Gesundheitswesen 2005; 67 S1: S176-S179

Anmerkung

* Die MONICA/KORA-Studiengruppe besteht aus: KORA: H.-E. Wichmann (Sprecher), H. Löwel, C. Meisinger, T. Illig, R. Holle, J. John und deren Mitarbeitern, die verantwortlich für das Design und die Durchführung der KORA-Studien sind: MONICA: U. Keil (Studienleiter), A. Döring, B. Filipiak, H. W. Hense, H. Löwel, J. Stieber und den Mitarbeitern, die verantwortlich für das Design und die Durchführung der MONICA-Studien waren.

Institutsangaben

GSF-Forschungszentrum für Umwelt und Gesundheit Institut für Epidemiologie, Neuherberg

Korrespondenzadresse

Anna Paulini · GSF-Forschungszentrum für Umwelt und Gesundheit Institut für Epidemiologie · Ingolstädter Landstr. 1·85764 Neuherberg · E-mail: Anna.paulini@gsf.de

Bibliografie

Gesundheitswesen 2005; 67 Sonderheft 1: S198 -S208 @ Georg Thieme Verlag KG Stuttgart • New York DOI $10.1055 / \mathrm{s}-2005-858402$

ISSN 0949-7013 
${ }^{20}$ Chambless L, Keil U, Dobson A, Mähönen M, Kuulasmaa K, Rajakangas AM, Löwel H, Tundstall-Pedoe H. Population versus clinical view of case fatality from acute coronary heart disease. Results from the WHO MONICA Project 1985 - 1990. Circulation 1997; 96: 3849- 3859

${ }^{21}$ Cholmakow-Bodechtel C, Döring A, Winkler G. Zum Einfluß von Ernährungsdatenbanken auf die Ergebnisse von Ernährungserhebungen - ein Vergleich von BLS-Version 2.1 und 2.2. Ernährungs-Umschau 1997; 44: 180-185

22 Colling M, Weggemann S, Döring A, Keil U, Wolfram G. Ernährungserhebung bei Erwachsenen mit 7-Tage-Protokoll - eine Pilotstudie im MONICA-Projekt Augsburg. Öffentl Gesundheitswes 1989; 51: 94-97

${ }^{23}$ Danser AH, Derkx FH, Hense HW, Jeunemaitre X, Riegger GA, Schunkert $\mathrm{H}$. Angiotensinogen (M235T) and angiotensinogen-converting enzyme (I/D) polymorphisms in association with plasma renin and prorenin levels. J Hypertens 1998; 16: 1879-1883

${ }^{24}$ Dobson A, Filipiak B, Kuulasmaa K, Beaglehole R, Stewart A, Hobbs M, Parsons R, Keil U, Greiser E, Korhonen H, Tuomilehto J. Relations of changes in coronary heart disease rates and changes in risk factor levels: Methodological issues and a practical example. Am J Epidemiol 1996; 143: $1025-1034$

${ }^{25}$ Dobson AJ, Kuulasmaa K, Eberle E, Scherer J. Confidence intervals for weighted sums of Poisson parameters. Stat Med 1991; 10: 457-462

${ }^{26}$ Döring A, Filipiak B, Stieber J, Keil U. Trends in alcohol intake in a Southern German population from 1984/85 to 1989/90: Results of the MONICA Project Augsburg. J Stud Alcohol 1993; 54: 745 - 749

27 Döring A, Filipiak B, Stieber J, Keil U. Trends in oral contraceptive use in a Southern German population. Results of the MONICA project Augsburg: Surveys 1984/85 and 1989/90. Eur J Public Health 1993. 3: $177-180$

${ }^{28}$ Döring A, Filipiak B, Winkler G, Keil U. Awareness and treatment of hypercholesterolemia: Results of the first MONICA Project Augsburg. Soz Praventivmed 1989; 34: 10 - 14

29 Döring A, Fröhlich M, Löwel H, Koenig W. Third generation oral contraceptive use and cardiovascular risk factors. Atherosclerosis 2004; 172: $281-286$

${ }^{30}$ Döring A, Hense HW, Stieber J, Keil U. Prävalenz des Übergewichts: Ergebnisse in einer süddeutschen Bevölkerung im nationalen Vergleich. Münch Med Wochenschr 1992; 134: 480-482

31 Döring A, Meisinger C, Thorand B, Löwel H, für die MONICA/KORAStudiengruppe. Ernährungsverhalten und Übergewicht: Untersuchungen in den MONICA/KORA-Studien. Gesundheitswesen 2005; 67 S1: S51 - S56

32 Döring A, Pajak A, Ferrario M, Grafnetter D, Kuulasmaa K. Methods of total cholesterol measurement in the baseline survey of the WHO MONICA Project. Rev Epidemiol Sante Publique 1990; 38: 455 - 461

33 Döring A, Stieber J, Schaeffler V, Winkler G, Keil U. Repräsentative Erhebungen der Alkoholaufnahme in Nord- und Süddeutschland. Ernährungs-Umschau 1992; 39: 3-7

${ }^{34}$ Eberle E, Döring A, Keil U. Weight change and change of total cholesterol and high-density-lipoprotein cholesterol: Results of the MONICA Augsburg Cohort Study. Ann Epidemiol 1991; 1: 487-492

${ }^{35}$ Eller M, Mielck A, Landgraf R. 'Freunde machen den Zucker süß!' Eine Literaturübersicht über den Zusammenhang zwischen Diabetes mellitus und dem sozialen Netzwerk bzw. sozialer Unterstützung. In: Bauer P, Otto U (Hrsg). Mit Netzwerken professionell zusammenarbeiten. Bd.1: Soziale Netzwerke in Lebenslauf- und Lebenslagenperspektive. Tübingen: dgvt-Verlag, 2005

${ }^{36}$ Eller M, Satzinger W, Holle R, Meisinger C, Thorand B, für die MONICA/KORA-Studiengruppe. Disease Management Programme in Deutschland: Erste Reaktionen der Diabetiker. Gesundheitswesen 2005; 67 S1: S144-S149

37 Engel S, Kleinle-Mayer A, Löwel H. Mortalität und funktionelle Einschränkungen bei chronisch Kranken: Ergebnisse einer Follow-upStudie an älteren Patienten nach Herzinfarkt. gesundh-wes 1997; 59 (Sonderheft 1): 26-33

${ }^{38}$ Engel S, Kleinle-Mayer A, Löwel H. Patterns of the functional status of chronically diseased as a part of the health status. Results of a followup study on elderly patients after myocardial infarction. In: D'Ansel$\mathrm{mi}$ A (Hrsg). Towards an integrated system of indicators to assess the health status of the population. Rom: ISTAT, 1999: 205-217

${ }^{39}$ Ernst E, Koenig W, Matrai A, Filipiak B, Stieber J. Blood rheology in healthy cigarette smokers. Results from the MONICA Project Augsburg. Arteriosclerosis 1988; 8: 385-388

${ }^{40}$ Ernst E, Koenig W, Matrai A, Keil U. Hämorheologische Variablen bei manifesten arteriellen Gefässerkrankungen. Vasa 1986; 15: 365 - 372

${ }^{41}$ Evans A, Tolonen H, Hense HW, Ferrario M, Sans S, Kuulasmaa K. Trends in coronary risk factors in the WHO MONICA Project. Internat J Epidemiol 2001; 30: $35-40$

42 Fibrinogen Studies Collaboration. Collaborative meta-analysis of prospective studies of plasma fibrinogen and cardiovascular disease. Eur J Cardiovasc Prev Rehabil 2004; 11: 9-17

${ }^{43}$ Filipiak B, Heinrich J, Nowak D, Wichmann HE. The distribution in specific IgE and the prevalence of allergic symptoms in 25 to 64 years old inhabitants of an eastern and a western Germany city - Results from Augsburg and Erfurt. Eur J Epidemiol 2001; 17: 77 - 84

${ }^{44}$ Filipiak B, Heinrich J, Schäfer T, Ring J, Wichmann HE. Farming, rural lifestyle and atopy in adults from southern Germany - Results from the MONICA/KORA Study Augsburg. Clin Exp Allergy 2001; 31: $1829-1838$

${ }^{45}$ Fischer B, Döring A. Häufigkeit der Einnahme von Vitamin- und $\mathrm{Mi}$ neralstoffpräparaten. Vergleich nationaler und internationaler Studien. Ernährungs-Umschau 1999; 46: 44-47

${ }^{46}$ Fischer B, Gulder S, Döring A. Zufuhr von Vitaminen und Mineralstoffen aus Nahrungsergänzungspräparaten: Ergebnisse der Augsburger MONICA-Querschnittsstudie 1994/95 und deren Follow-up 1998. In: Vitamine und Zusatzstoffe in der Ernährung von Mensch und Tier 7. Symposium Sept. 1999 Jena. Gera: Gebrüder Frank KG, 1999: 189-192

${ }^{47}$ Fischer M, Baessler A, Hense HW, Hengstenberg C, Muscholl M, Holmer S, Döring A, Broeckel U, Riegger G, Schunkert H. Prevalence of left ventricular diastolic dysfunction in the community. Results from a Doppler echocardiographic-based survey of a population sample. Eur Heart J 2003; 24: 320 - 328

${ }^{48}$ Fischer M, Baessler A, Holmer SR, Muscholl M, Bröckel U, Luchner A, Hense HW, Döring A, Riegger G, Schunkert H. Epidemiologie der linksventrikulären systolischen Dysfunktion in der Allgemeinbevölkerung Deutschlands: Ergebnisse echokardiografischer Untersuchungen einer großen Bevölkerungsstichprobe. Z Kardiol 2003; 92: $294-302$

${ }^{49}$ Fischer M, Bäßler A, Hengstenberg C, Holmer S, Mayer B, Löwel H, Riegger G, Klein G, Schunkert H. ACE-Inhibition bei Myokardinfarkten mit eingeschränkter Ventrikelfunktion: Umsetzung von Therapiestandards in Bevölkerungsstichproben. Z Kardiol 2001; 90: 104-110

${ }^{50}$ Fischer M, Lieb W, Marold D, Berthold M, Baessler A, Loewel H, Hense HW, Hengstenberg C, Holmer S, Schunkert H, Erdmann J. Lack of association of a $9 \mathrm{bp}$ insertion-/deletion polymorphism within the bradykinin 2 receptor gene with myocardial infarction. Clin Sci 2004; 107: $505-511$

${ }^{51}$ Fischer R, Wildner M, Brunner A. Gesundheit und Menschenrechte Entwicklung eines Fragebogens zur Messung des empfundenen Menschenrechtsstatus. Soz Praventivmed 2000; 45: $161-173$

52 Fröhlich M, Döring A, Imhof A, Hutchinson WL, Pepys MB, Koenig W. Oral contraceptive use is associated with a systemic acute phase response. Fibrinolysis and Proteolysis 1999; 13: 239-244

${ }^{53}$ Fröhlich M, Mühlberger N, Hanke H, Imhof A, Döring A, Pepys MB, Koenig W. Markers of inflammation in women on different hormone replacement therapies. Ann Med 2003; 35: 353-361

${ }^{54}$ Fröhlich M, Schunkert H, Hense HW, Torpitzsch A, Hendricks P, Döring A, Riegger GAJ, Koenig W. Effects of hormone replacement therapies on fibrinogen and plasma viscosity in postmenopausal women. Brit J Haematol 1998; 100: 577-581

${ }^{55}$ Fröhlich M, Sund M, Löwel H, Imhof A, Hoffmeister A, Koenig W. Independent association of various smoking characteristics with markers of systemic inflammation in men. Results from a representative sample of the general population (MONICA Augsburg Survey 1994/95). Eur Heart J 2003; 24: 1365 - 1372

${ }^{56}$ Fröhlich M, Sund M, Thorand B, Hutchinson LH, Pepys MB, Koenig W. Lack of seasonal variation in C-Reactive protein. Clin Chemistry 2002; 48: $575-577$

${ }^{57}$ Gasse C, Hense HW, Stieber J, Döring A, Liese A, Heller G, Keil U. Factors associated with differences in antihypertensive drug treatment: results from the MONICA Augsburg Population Surveys 1989/90 and 1994/95. Soz Praventivmed 2002; 47: 128-139

${ }^{58}$ Gasse C, Hense HW, Stieber J, Döring A, Liese AD, Keil U. Assessing hypertension management in the community: trends of prevalence, detection, treatment, and control of hypertension in the MONICA Project, Augsburg 1984-1995. J Hum Hypertens 2001; 15: 27-36 
${ }^{59}$ Gasse C, Stieber J, Döring A, Keil U, Hense HW. Population trends in antihypertensive drug use: Results from the MONICA Augsburg Project 1984 to 1995. J Clin Epidemiol 1999; 52: 695-703

${ }^{60}$ Gehring J, Perz S, Stieber J, Küfner R, Keil U. Cardiovascular risk factors, ECG abnormalities and quality of life in subjects with atrial fibrillation. Soz Praventivmed 1996; 41: 185-193

${ }^{61}$ Geller F, Reichwald K, Dempfle A, Illig T, Vollmert C, Herpertz S, Siffert W, Platzer M, Hess C, Gudermann T, Biebermann H, Wichmann HE, Schäfer H, Hinney A, Hebebrand J. Melanocortin-4 receptor gene variant i103 is negatively associated with obesity. Am J Hum Genet 2004; $74: 572-581$

62 Gostomzyk JG, Heller WD, Gerhardt P, Lee PN, Keil U. B-Scan ultrasound examination of the carotid arteries within a representative population (MONICA Project Augsburg). Klin Wochenschr 1988; 66 (Suppl. 11): 58-65

${ }^{63}$ Gostynski M, Gutzwiller F, Kuulasmaaa K, Döring A, Ferrario M, Grafnetter D, Pajak A. Analysis of the relationship between total cholesterol, age, body mass index among males and females in the WHO MONICA project. Int J Obesity 2004; 28: $1082-1090$

${ }^{64}$ Härtel U, Chambless L. Occupational position and type A behavior: Results from the first MONICA survey Augsburg, F.R.G. Soc Sci Med 1989; 29: $1367-1372$

${ }^{65}$ Härtel U, Heiss G, Filipiak-Pittroff B, Döring A. Cross-sectional and longitudinal associations between high density lipoprotein cholesterol and women's employment. Am J Epidemiol 1992; 135: 68 - 78

${ }^{66}$ Härtel U, Keil U, Helmert U, Greiser E, Dai S, Gutzwiller F, Folsom AR, Szklo M, White AD, Schreiner PJ, Tyroler HA. The association of coronary risk factors with educational achievement: Results of the ARICMONICA Collaborative Studies. Ann Epidemiol 1993; 3 (Suppl. 5): $55-61$

${ }^{67}$ Härtel U, Keil U. Psychosoziale Faktoren und Herz-Kreislauf-Erkrankungen. Laufende Studien und erste Ergebnisse im MONICA-Projekt Augsburg der WHO. Fortschr Med 1986; 104: 943 - 947

68 Härtel U, Löwel H. Familienstand und Überleben nach Herzinfarkt: Ergebnisse des MONICA-Augsburg Herzinfarktregisters. Münch Med Wochenschr 1991; 133: 464-468

${ }^{69}$ Härtel U, Stieber J, Keil U. Der Einfluß von Ausbildung und beruflicher Position auf Veränderungen im Zigarettenrauchen und Alkoholkonsum: Ergebnisse der MONICA Augsburg Kohortenstudie. Soz Praventivmed 1993; 38: 133-141

\$200 $\quad{ }^{70}$ Härtel U, Stieber J, Keil U. Social relations and smoking behavior: Results from the first MONICA Survey Augsburg. Soz Praventivmed 1988; $33: 27-31$

${ }^{71}$ Heid IM, Lamina C, Bongardt F, Fischer G, Klopp N, Huth C, Küchenhoff $\mathrm{H}$, Kronenberg F, Wichmann HE, Illig T. Wie gut können Haplotypen in den populationsbasierten KORA Studien rekonstruiert werden? Gesundheitswesen 2005; 67 S1: S132 - S136

${ }^{72}$ Heidrich J, Liese A, Löwel H, Keil U. Self-Rated Health and its Relation to All-Cause and Cardiovascular Mortality in Southern Germany. Results from the MONICA Augsburg Cohort Study 1984-1995. Ann Epidemiol 2002; 12: $338-345$

${ }^{73}$ Heidrich J, Wellmann J, Hense HW, Siebert E, Liese AD, Löwel H, Keil U. Klassische Risikofaktoren für Herzinfarkt und Gesamtsterblichkeit in der Bevölkerung: 13-Jahres-Follow-up der MONICA Augsburg-Kohortenstudie. Z Kardiol 2003; 92: 445 - 454

${ }^{74}$ Heinrich J, Döring A. Blood pressure and rhinitis in adults: result of the MONICA/KORA-study. J Hypertens 2004; 22: 889-892

${ }^{75}$ Hendricks PT, Kuch B, Bröckel U, Muscholl M, Döring A, Schunkert H, Hense HW. Bevölkerungsdeterminanten von Größe und Form des linken Ventrikels. Nieren- und Hochdruckkrankh 1997; 26: 179-181

${ }^{76}$ Hengstenberg C, Holmer S, Mayer B, Engel S, Schneider A, Löwel H, Riegger G, Schunkert H. Siblings of myocardial infarction patients are overlooked in primary prevention of cardiovascular disease. Eur Heart J 2001; 22: 926-933

${ }^{77}$ Hengstenberg C, Holmer SR, Mayer B, Löwel H, Engel S, Hense HW, Riegger GAJ, Schunkert H. Evaluation of the aldosterone synthase (CYP11B2) gene polymorphism in patients with myocardial infarction. Hypertension 2000; 35: 704-709

78 Hengstenberg C, Schunkert H, Mayer B, Döring A, Löwel H, Hense HW, Fischer M, Riegger GAJ, Holmer SR. Association between a polymorphism in the G protein $B 3$ subunit gene (GNB3) with arterial hypertension but not with myocardial infarction. Cardiovasc Res 2001; 49: $820-827$

${ }^{79}$ Hense H, Schulte H, Löwel H, Assmann G, Keil U. Framington risk function overestimates risk of coronary heart disease in men and women from Germany - Results from the MONICA Augsburg and the PROCAM cohorts. Eur Heart J 2003; 24: 937-945

${ }^{80}$ Hense HW, Döring A, Stieber J, Keil U. The association of antihypertensive treatment patterns and adverse lipid effects in populationbased studies. J Clin Epidemiol 1992; 45: 1423 - 1430

${ }^{81}$ Hense HW, Filipiak B, Döring A, Stieber J, Liese A, Keil U. Ten-year trends of cardiovascular risk factors in the MONICA Augsburg Region in southern Germany. Results from the 1984/85, 1989/90, and 1994/95 Surveys. CVD Prevention 1998; 1: 318 - 327

82 Hense HW, Filipiak B, Keil U. Alcohol consumption as a modifier of the relation between blood lead and blood pressure. Epidemiology 1993; 5: $120-123$

${ }^{83}$ Hense HW, Filipiak B, Keil U. The association of blood lead and blood pressure in population surveys. Epidemiology 1993; 4: 173-179

${ }^{84}$ Hense HW, Filipiak B, Novak L, Stoeppler M. Nonoccupational determinants of blood lead concentrations in a general population: Results from the MONICA-Augsburg Project. Int J Epidemiol 1992; 21: $753-762$

${ }^{85}$ Hense HW, Gneiting B, Muscholl M, Bröckel U, Kuch B, Döring A, Riegger GAJ, Schunkert $\mathrm{H}$. The associations of body size and body composition with left ventricular mass: Impact for indexation in adults. J Am Coll Cardiol 1998; 32: 451 - 457

${ }^{86}$ Hense HW, Koenig W, Heller WD, Sennewald E, Gostomzyk JG, Keil U. Determinanten atherosklerotischer Plaques in den Karotis- und Femoralarterien. Nieren- und Hochdruckkrankh 1994; 23: 503-506

${ }^{87}$ Hense HW, Koivisto AM, Kuulsmaa K, Zaborskis A, Kupsc W, Tuomilehto J. Assessement of blood pressure measurement quality in the baseline surveys of the WHO MONICA Project. J Hum Hypertens 1995; 9: 935 - 946

${ }^{88}$ Hense HW, Krobot K, Cremer P, Stieber J, Keil U. Arterieller Blutdruck und Plasmafibrinogen. Ergebnisse des MONICA Augsburg Surveys von 1989/90. Nieren- und Hochdruckkrankh 1992; 21: 646-648

${ }^{89}$ Hense HW, Kuulasmaa K, Zaborskis A, Kupsc W, Tuomilehto J. Quality assessment of blood measurements in epidemiological surveys. The impact of last digit preference and the proportions of identical duplicate measurements. Rev Epidemiol Sante Publique 1990; 38: $463-468$

${ }^{90}$ Hense HW, Stender M, Bors W, Keil U. Lack of an association between serum vitamin $\mathrm{E}$ and myocardial infarction in a population with high vitamin E levels. Atherosclerosis 1993; 103: 21 - 28

${ }^{91}$ Hense HW, Stender M, Filipiak B, Löwel H, Lewis M, Döring A, Stieber J, Keil U. Blutdruckhöhe, Inzidenz des Myokardinfarktes und Sterberisiko: Die MONICA Augsburg Kohortenstudie 1984-1991. Nieren- und Hochdruckkrankh 1993; 22: $292-296$

92 Hense HW, Stieber J, Filipiak B, Keil U. Five-year changes in population blood pressure and hypertension prevalence: Results from the MONICA Augsburg Surveys 1984/85 and 1989/90. Ann Epidemiol 1993; 3: 410-416

${ }^{93}$ Hense HW, Tennis P. Changing patterns of antihypertensive drug use in a German population between 1984 and 1987. Results of a population based cohort study in the Federal Republic of Germany. Eur J Clin Pharmacol 1990; 39: $1-7$

${ }^{94}$ Herbon N, Werner M, Braig C, Gohlke H, Dütsch G, Illig T, Altmüller J, Hampe J, Lantermann A, Schreiber S, Bonifacio E, Ziegler A, Schwab S, Wildenauer D, van den Boom D, Braun A, Knapp M, Reitmeir P, Wjst M. High-resolution SNP scan of chromosome $6 \mathrm{p} 21$ in pooled samples from patients with complex diseases. Genomics 2003; 81: 510-518

${ }^{95}$ Herder C, Illig T, Rathmann W, Martin S, Haastert B, Müller-Scholze S, Holle R, Thorand B, Koenig W, Wichmann HE, Kolb H, for the KORA Study Group. Inflammation and Type 2 Diabetes: Results from KORA Augsburg. Gesundheitswesen 2005; 67 S1: S115-S121

${ }^{96}$ Hering R, Petrovic S, Mietz EM, Holzmann C, Berg D, Bauer P, Woitalla D, Müller T, Berger K, Krüger R, Riess O. Extended mutation analysis and association studies of Nurr1 (NR4A2) in Parkinson's Disease. Neurology 2004; 62: $1231-1232$

${ }^{97}$ Holle R, Giesecke B, Nagl H. PC-gestützte Datenerhebung als Beitrag zur Qualitätssicherung in Gesundheitssurveys: Erfahrungen mit DAIMON im KORA-Survey 2000. Zeitschrift für Gesundheitswissenschaften 2000; 8: 165-173

${ }^{98}$ Holle R, Happich M, Löwel H, Wichmann HE, for the KORA Study Group. KORA - A research platform for population based health research. Gesundheitswesen 2005; 67 S1: S19-S25 
${ }^{99}$ Holmer S, Hengstenberg C, Mayer B, Engel S, Löwel H, Riegger GAJ, Schunkert H. Marked suppression of renin levels by beta-receptor blocker in patients treated with standard heart failure therapy: a potential mechanism of benefit from beta-blockade. J Intern Med 2001; 249: $167-172$

${ }^{100}$ Holmer SH, Hengstenberg C, Mayer B, Döring A, Löwel H, Engel S, Hense HW, Wolf M, Klein G, Riegger GAJ, Schunkert H. Lipoprotein lipase gene polymorphism, cholesterol subfractions and myocardial infarction in large samples of the general population. Cardiovasc Res 2000; 47: 806-812

${ }^{101}$ Holmer SR, Bickeböller H, Hengstenberg C, Rohlmann F, Engel S, Löwel H, Mayer B, Erdmann J, Baier C, Klein G, Riegger GAJ, Schunkert $\mathrm{H}$. Angiotensin converting enzyme gene polymorphism and myocardial infarction a large association and linkage study. Int J Biochem Cell B 2003; 35: 955-962

102 Holmer SR, Hengstenberg C, Kraft HG, Mayer B, Pöll M, Kürzinger S, Fischer M, Löwel H, Klein G, Riegger GAJ, Schunkert H. Association of polymorphisms of the apolipoprotein(a) gene with lipoprotein(a) levels and myocardial infarction. Circulation 2003; 107: 696-701

103 Holmer SR, Hense HW, Danser AH, Mayer B, Riegger GA, Schunkert H. Beta-adrenergic blockers lower renin in patients treated with ACE inhibitors and diuretics. Heart 1998; 80: 45-48

${ }^{104}$ Holzmann C, Krüger R, Saecker AS, Schmitt I, Schöls L, Berger K, Riess O. Polymorphisms of the $\alpha$-synuclein promotor: expression analyses and association studies in Parkinson's disease. J Neural Transm 2003; 110: $67-76$

${ }^{105}$ Hoppe S, Holle R. Beitrag einer zentralen Datenhaltung zur Qualitätssicherung in KORA. Z Gesundheitswissen 2000; 8: 158 - 164

${ }^{106}$ Hutchinson WL, Koenig W, Frohlich M, Sund M, Lowe GD, Pepys MB. Immunoradiometric assay of circulating $C$-reactive protein: age-related values in the adult general population. Clin Chem 2000; 46: 934-938

107 Ibald-Mulli A, Stieber J, Wichmann HE, Koenig W, Peters A. Effects of air pollution on blood pressure: A population-based approach. Am J Public Health 2001; 91: $571-577$

108 Icks A, Haastert B, Gandjour A, John J, Löwel H, Holle R, Giani G, Rathmann W, for the KORA Study Group. Cost-effectiveness of different screening procedures for type 2 diabetes: The KORA survey 2000. Diabetes Care 2004; 27: 2120-2128

${ }^{109}$ Icks A, Rathmann W, Haastert B, John J, Löwel H, Holle R, Giani G, for the KORA Study Group. Cost-effectiveness of type 2 diabetes screening: Results from recently published studies. Gesundheitswesen 2005; 67 S1: S158-S166

110 Illig T, Bongardt F, Schöpfer A, Holle R, Müller S, Rathmann W, Meisinger C, Wichmann HE, Kolb H, KORA Study Group. The endotoxin receptor TLR 4 polymorphism is not associated with diabetes or components of the metabolic syndrome. Diabetes 2003; 52: $2861-2864$

111 Illig T, Bongardt F, Schöpfer A, Müller-Scholze S, Rathmann W, Koenig W, Thorand B, Vollmert C, Holle R, Kolb H, Herder C, and Members of the Kooperative Gesundheitsforschung im Raum Augsburg/Cooperative Research in the Region of Augsburg (KORA). Significant association of the interleukin-6 gene polymorphisms C-174G and A-598G with type 2 diabetes. J Clin Endocrinol Metab 2004; 89: 5053 - 5058

112 Illig T, Bongardt F, Schöpfer-Wendels A, Huth C, Heid I, Rathmann W, Martin S, Vollmert C, Holle R, Thorand B, Wichmann HE, Koenig W, Kolb H, Herder C, for the KORA Study Group. Genetics of Type 2 Diabetes: Impact of Interleukin-6 Gene Variants. Gesundheitswesen 2005; 67 S1: S115-S121

113 Imhof A, Fröhlich M, Löwel H, Helbecque N, Woodward M, Amouyel P, Lowe GDO, Koenig W. Distributions of C-reactive protein measured by high-sensitivity assays in apparently healthy men and women from different populations in europe. Clin Chemistry 2003; 49: $669-672$

114 Imhof A, Woodward M, Döring A, Helbecque N, Löwel H, Amouyel P, Lowe GDO, Koenig W. Overall alcohol intake, beer, wine and systemic markers of inflammation in western Europe: results from three MONICA samples (Augsbrug, Glasgow, Lille). Eur Heart J 2004; 25: $2092-2100$

115 Jamshidi Y, Montgomery HE, Hense HW, Myerson S, Torra IP, Staels B, World MJ, Döring A, Erdmann J, Hengstenberg C, Humphries SE, Path FRC, Schunkert H, Flavell D. Peroxisome Proliferator-activated receptor $\alpha$ gene regulates left ventricular growth in response to exercise and hypertension. Circulation 2002; 105: 950-955
${ }^{16}$ Jeron A, Hengstenberg C, Engel S, Löwel H, Riegger GAJ, Schunkert H, Holmer S. The D-allele of the ACE polymorphism is related to increased QT dispersion in 609 patients after myocardial infarction. Eur Heart J 2001; 22: $663-668$

117 Jeron A, Kaiser T, Hengstenberg C, Löwel H, Riegger GAJ, Holmer S. Association of the heart rate turbulence with classic risk stratification parameters in postmyocardial infarction patients. A N E 2003; 8: $296-301$

118 John J, Holle R. Probleme der Erschließung und Nutzung von Daten der gesetzlichen Krankenversicherung für bevölkerungsbezogene gesundheitsökonomische Evaluationsstudien: Erfahrungen aus KORA Inform Biom Epidemiol Med und Biol 2003; 34: 96-111

119 Justenhoven C, Hamann U, Pesch B, Harth V, Rabstein S, Baisch C, Vollmert C, Illig T, Ko Y, Brüning T, Brauch H, for the GENICA Network Cancer (2004). ERCC2 genotypes and a corresponding haplotype are linked with breast cancer risk in a German association study. Cancer Epidemiol Biomarker Prev 2004; 13 (12): 2059-2064

${ }^{120}$ Keil U, Chambless L, Filipiak B, Härtel U. Alcohol and blood pressure and its interaction with smoking and other behavioural variables: Results from the MONICA Augsburg Survey 1984-1985. J Hypertens 1991; 9: 491 - 498

${ }^{121}$ Keil U, Chambless LE, Döring A, Filipiak B, Stieber J. The relation of alcohol intake to coronary heart disease and all-cause mortality in a beer-drinking population. Epidemiology 1997; 8: 150-156

122 Keil U, Chambless U, Döring A, Filipiak B, Stieber J. Alkoholkonsum, koronare Herzkrankheit und Gesamtmortalität in einer biertrinkenden Bevölkerung Süddeutschlands. Fortschr Med 1998; 116: 5-13 (und in: Kluthe R, Kasper H, Gebhardt A (Hrsg). Alkoholische Getränke und Ernährungsmedizin. Stuttgart/New York: Thieme, 1998: 20-31)

${ }^{123}$ Keil U, Filipiak B, Döring A, Hense HW, Lewis M, Löwel H, Stieber J. Monitoring trends and determinants in cardiovascular disease in Germany: Results of the MONICA Project Augsburg, 1985 - 1990. MMWR 1992; $41: 171-179$

${ }^{124}$ Keil U, Filipiak B, Döring A, Hense HW, Löwel H, Stieber J. Epidemiologische Daten zur Häufigkeit des Rauchens in Ost- und Westdeutschland und zu Veränderungen des Rauchverhaltens und der koronaren Herzkrankheit im süddeutschen Raum. Immun Environm 1995; 9: $17-30$

${ }^{125}$ Keil U, Liese A, Filipiak B, Swales JD, Grobbee DE. Alcohol, blood pressure and hypertension. In: Chadwick DJ, Goodee JA, Chichester GB (Hrsg). Alcohol and Cardiovascular Diseases John Wiley \& Sons, 1998: $125-151$

${ }^{126}$ Keil U, Liese AD, Hense HW, Filipiak B, Döring A, Stieber J, Löwel H. Classical risk factors and their impact on incident non-fatal and fatal myocardial infarction and all-cause mortality in southern Germany. Results from the MONICA Augsburg cohort study 1984-1992. Eur Heart J 1998; 19: 1197-1207

${ }^{127}$ Keil U, Stieber J, Döring A, Chambless L, Härtel U, Filipiak B, Hense HW, Tietze M, Gostomzyk JG. The cardiovascular risk factor profile in the study area Augsburg. Results from the first MONICA survey 1984/85. Acta Med Scand Suppl 1988; 728: 119-128

${ }^{128}$ Keil U. Das weltweite WHO MONICA Projekt: Ergebnisse und Ausblick. Gesundheitswesen 2005; 67 S1: S38-S45

${ }^{129}$ Keil U. Herz-Kreislauf-Prävention. Projekt MONICA - deutscher Beitrag zur Erforschung kardiovaskulärer Risiken. Fortschr Med 1984; 102: 9

130 Keil U. MONICA-Project. Herz-Kreislauf-Studie der Weltgesundheitsorganisation. Herz Kreislauf 1985; 2: 99

131 Klein T, Schneider S, Löwel H. Bildung und Mortalität. Die Bedeutung gesundheitsrelevanter Aspekte des Lebensstils. Z Soziologie 2001; 30: $384-400$

132 Klemm E, Merkl J, Wichmann HE, Ring J, Schäfer T. Atopie bei Mensch und Haustier. Allergo J 2001; 10: 324-325

${ }^{133}$ Klopp N, Héon E, Billingsley G, Illig T, Wjst M, Rudolph G, Graw J. Further Genetic Heterogeneity for Autosomal Dominant Human Sutural Cataracts. Ophtalmic Res 2002; 35: 71-77

${ }^{134}$ Koch A, Hörmann A, Löwel H, Senges J. „The 60-Minutes-Myocardial Infarction Project“: Comparison with a registry and a randomized clinical trial. In: Abel U, Koch A (Hrsg). Nonrandomized Comparative Clinical Studies. Düsseldorf: Symposion Publishing, 1998: 149-160

135 Koenig W, Khuseyinova N, Loewel H, Trischler G, Meisinger C. Lipoprotein-associated phospholipase A2 adds to risk prediction of incident coronary events by C-reactive protein in apparently healthy 

the general population. Circulation 2004; 110: $1903-1908$

${ }^{136}$ Koenig W, Loewel H, Baumert J, Meisinger C. C-reactive protein modulates risk prediction based on the Framingham Score. Implications for future risk assessment: Results from a large cohort study in southern Germany. Circulation 2004; 109: 1349-1353

137 Koenig W, Löwel H, Lewis M, Hörmann A. Long-term survival after myocardial infarction: relationship with thrombolysis and discharge medication. Results of the Augsburg Myocardial Infarction Follow-up Study 1985 to 1993. Eur Heart J 1996; 17: 1199-1206

138 Koenig W, Löwel H. Cardiovascular disease in women. Epidemiology and problems in management. In: Femmes \& Nutrition (Hrsg). Actualités et Implications Pratiques. 2001: 73 -86

139 Koenig W, Meisinger C, Baumert J, Khuseyinova N, Löwel H. Systemic low-grade inflammation and risk of coronary heart disease: Results from the MONICA/KORA-Augsburg cohort studies. Gesundheitswesen 2005; 67 S1: S62 - S67

${ }^{140}$ Koenig W, Meisinger C, Löwel H. Epidemiologie koronarer Ereignisse bei Diabetes mellitus. In: Meinertz T, Rösen P, Schömig A, Tschöpe D, Ziegler D (Hrsg). Diabetes und Herz. Steinkopff Verlag, 2005: 3-12

${ }^{141}$ Koenig W, Sund M, Döring A, Ernst E. Leisure-time physical activity but not work-related physical activity is associated with decreased plasma viscosity. Results from a large population sample. Circulation 1997; 95: $335-341$

142 Koenig W, Sund M, Ernst E, Keil U, Rosenthal J, Hombach V. Association between plasma viscosity and blood pressure. Results from the MONICA-Project Augsburg. Am J Hypertens 1991; 4: 529-536

${ }^{143}$ Koenig W, Sund M, Ernst E, Matrai A, Keil U, Rosenthal J. Is increased plasma viscosity a risk factor for high blood pressure? Angiology 1989; 40: 153 - 163

${ }^{144}$ Koenig W, Sund M, Ernst E, Mraz W, Hombach V, Keil U. Association between rheology and components of lipoproteins in human blood: Results from the MONICA Project. Circulation 1992; 85: 2197 - 2204

145 Koenig W, Sund M, Filipiak B, Döring A. Plasma viscosity and the risk of coronary heart disease. Results from the MONICA-Augsburg Cohort Study, 1984 to 1992. Arterioscler Thromb Vasc Biol 1998; 18: $768-772$

146 Koenig W, Sund M, Fröhlich M, Fischer HG, Löwel H, Döring A, Hutchinson WL, Pepys MB. C-reactive protein, a sensitive marker of inflammation, predicts future risk of coronary heart disease in initially healthy middle-aged men. Circulation 1999; 99: 237-242

${ }^{147}$ Koenig W, Sund M, Fröhlich M, Löwel H, Winston L, Hutchinson WL, Pepys MB. Refinement of the association of serum C-reactive protein concentration and coronary heart disease risk by correction for within-subject variation over time. The MONICA-Augsburg Studies, 1984 and 1987. Am J Epidemiol 2003; 158: 357 - 364

${ }^{148}$ Koenig W, Sund M, Lowe GDO, Lee AJ, Resch KL, Tunstall-Pedoe H, Keil U, Ernst E. Geographical variations in plasma viscosity and relation to coronary event rates. Lancet 1994; 344: 711 - 714

149 Koenig W, Sund M, Löwel H, Döring A, Ernst E. Association between plasma viscosity and all-cause mortality: results from MONICAAugsburg Cohort Study 1984-92. Brit J Haematol 2000; 109: $453-458$

${ }^{150}$ Koenig W, Sund M, Ernst E, Döring A, Keil U, Hombach V. HDL modifiziert die Plasmaviskosität bei Hypercholesterinämie. Perfusion $1991 ; 1+2: 9-15$

${ }^{151}$ Krobot K, Hense HW, Cremer P, Eberle E, Keil U. Determinants of plasma fibrinogen: Relation to body weight, waist-to-hip ratio, smoking, alcohol, age and sex: Results from the second MONICA-Augsburg Survey 1989/90. Arterioscler Thromb 1992; 12: 780 - 788

152 Krüger R, Menezes-Saecker AMV, Schöls L, Kuhn W, Müller T, Woitalla D, Berg D, Berger K, Pruntek H, Epplen JT, Riess O. Genetic analysis of the alpha-2-macroglobulin gene in early- and late-onset Parkinson's disease. Neuroreport 2000; 11: 2439-2442

${ }^{153}$ Kuch B, Bolte HD, Hörmann A, Meisinger C, Loewel H. What is the real hospital mortality from acute myocardial infarction? Eur Heart J 2002; 23: 714-720

${ }^{154}$ Kuch B, Gneiting B, Döring A, Muscholl M, Bröckel U, Schunkert H, Hense HW. Indexation of left ventricular mass in adults with a novel approximation for fat-free mass. J Hypertens 2001; 19: 135 - 142

${ }^{155}$ Kuch B, Hense HW, Gneiting B, Döring A, Muscholl M, Bröckel U, Schunkert $\mathrm{H}$. Body composition and prevalence of ventricular hypertrophy. Circulation 2000; 102: $405-410$
Kuch B, Löwel H, v Schneidt W. Einteilung des akuten Herzinfarktes nach EKG-morphologischen Kriterien - epidemiologische Daten und prognostische Implikationen. Z Kardiol 2003; 10: 103 - 106

${ }^{157}$ Kuch B, Muscholl M, Luchner A, Döring A, Riegger GAJ, Schunkert H, Hense HW. Gender specific differences in left ventricular adaptation to obesity and hypertension. J Hum Hypertens 1998; 12: 685-691

${ }^{158}$ Kuch B, Muscholl M, Luchner A, Döring A, Riegger GAJ, Schunkert H, Hense HW. Geschlechtsunterschiede in der Beziehung zwischen Übergewicht und Hypertonie mit links-ventrikulärer Masse und Hypertrophie. Z Kardiol 1996; 85: 334-342

159 Kuch B, Schunkert H, Muscholl M, Döring A, van Scheidt W, Hense HW, für die MONICA/KORA-Studiengruppe. Verteilung, Determinanten und Referenzwerte linksventrikulärer Parameter in der Allgemeinbevölkerung - Resultate der MONICA/KORA Echokardiographiestudien. Gesundheitswesen 2005; 67 S1: S68-S73

$160 \mathrm{Kußmaul} \mathrm{B}$, Döring A, Filipiak B. Bioelektrische Impedanzanalyse (BIA) in einer epidemiologischen Studie. Ernährungs-Umschau 1996; 43: $51-53$

${ }^{161}$ Kußmaul B, Döring A, Stender M, Winkler G, Keil U. Zusammenhang zwischen Ernährungsverhalten und Bildungsstand: Ergebnisse der Ernährungserhebung 1984/85 des MONICA-Projektes Augsburg. Z Ernährungswiss 1995; 34: 177-182

162 Ladwig KH, Baumert J, Löwel H, Döring A, Wichmann HE, for the Kora Study Investigators. Contemplating to quit current smoking status: Differences in behavioural and psychosocial patterns in a populationbased cohort of current smokers. Prev Med 2005; 41: 134-146

${ }^{163}$ Ladwig KH, Marten-Mittag B, Baumert J, Löwel H, Döring A, for the KORA investigators. Case-finding for depressive and exhausted mood in the general population: reliability and validity of a symptom-driven diagnostic scale. Results from the Prospective MONICA/ KORA Augsburg Study. Ann Epidemiol 2004; 14: 332 - 338

${ }^{164}$ Ladwig KH, Marten-Mittag B, Baumert J, für die MONICA/KORA-Studiengruppe. Psychosoziale Belastungsfaktoren als Risiko für das Auftreten einer koronaren Herzerkrankung - Eine Bestandsaufnahme unter besonderer Berücksichtigung der KORA-Forschungsplattform. Gesundheitswesen 2005; 67 S1: S86-S93

165 Ladwig KH, Marten-Mittag B, Löwel H, Döring A, Koenig W. Influence of depressive mood on the association of CRP and obesity in 3205 middle aged healthy men. Brain Behav Immun 2003; 17: 268 - 275

${ }^{166}$ Lamina C, Meisinger C, Heid IM, Rantner B, Döring A, Löwel H, Kronenberg F. Ankle-Brachial Index and Peripheral Arterial Disease. Gesundheitswesen 2005; 67 S1: S57 - S61

${ }^{167}$ Lamina C, Steffens M, Mueller J, Lohmussaar E, Meitinger T, Wichmann HE. Genetic diversity in German and European populations: Looking for substructures and genetic patterns. Gesundheitswesen 2005; 67 S1: S127-S131

${ }^{168}$ Launer LJ, Oudkerk M, Nilsson LG, Alperovitch A, Berger K, Breteler MMB, Fuhrer R, Giampaoli S, Nissinen A, Pajak A, Sans S, Schmidt R, Hofman A. CASCADE: A European collaborative study on vascular determinants of brain lesions. Neuroepidemiology 2000; 19: 113-120

169 Lederbogen F, Deuschle M, für die MONICA/KORA-Studiengruppe. Dysfunktion des Hypothalamus-Hypophysen-NebennierenrindenSystems - Hintergrundvariable relevanter kardiovaskulärer Risikofaktoren? Beschreibung eines kooperativen Projektes. Gesundheitswesen 2005; 67 S1: S94-S97

${ }^{170}$ Lewis M, Löwel H, Hörmann A. Die Arzneimittelbehandlung von Herzinfarktpatienten vor und nach dem Akutereignis: Ergebnisse des Herzinfarktregisters Augsburg. Soz Praventivmed 1994; 39 : $75-85$

${ }^{171}$ Lewis M, Löwel H, Stieber J, Engelbrecht R, Hörmann A, John J. Arzneimittelwechselwirkungen in den Verordnungen von Patienten vor und nach dem Herzinfarkt: Resultate des MONICA Augsburg Herzinfarktregisters. Soz Praventivmed 1991; 36: 9-17

172 Lieb W, Pavlik R, Erdmann J, Mayer B, Holmer SR, Fischer M, Bassler A, Hengstenberg C, Loewel H, Doering A, Riegger GA, Schunkert H. No association of interleukin-6 gene polymorphism (-174 G/C) with myocardial infarction or traditional cardiovascular risk factors. Int J Cardiol 2004; 97: 205-212

173 Liese AD, Döring A, Hense HW, Keil U. Five year changes in waist circumference, body mass index and obesity in Augsburg, Germany. Eur J Nutr 2001; 40: 282 - 288

174 Liese AD, Hense HW, Brenner H, Löwel H, Keil U. Assessing the impact of classical risk factors on myocardial infarction by rate advancement periods. Am J Epidemiol 2000; 152: $884-888$ 
${ }^{175}$ Liese AD, Hense HW, Döring A, Stieber J, Keil U. Microalbuminuria, central adiposity and hypertension in the non-diabetic urban population of the MONICA Augsburg survey 1994/95. J Hum Hypertens 2001; 15: 799-804

176 Liese AD, Hense HW, Löwel H, Döring A, Tietze M, Keil U. Association of uric acid with all-cause and cardiovascular mortality and incident myocardial infarction in the MONICA Augsburg cohort. Epidemiology 1999; 10: $391-397$

177 Löwel H, Dinkel R, Hörmann A, Stieber J, Görtler E. Herzinfarkt und Diabetes: Ergebnisse der Augsburger Herzinfarkt-Follow-up Studie 1985 bis 1990. Diabetes und Stoffwechsel 1996; 5: 19-23

178 Löwel H, Dobson A, Keil U, Herman B, Hobbs MST, Stewart A, Arstila M, Miettinen H, Mustaniemi H, Tuomilehto J. Coronary heart disease case fatality in four countries: A Community Study. Circulation 1993; 88: $2524-2531$

179 Löwel H, Döring A, Heier M, Meisinger C, Schneider A, Kaup U, Gösele U. Koronare Herzkrankheit, Akuter Myokardinfarkt. Gesundheitsberichterstattung des Bundes (im Druck)

${ }^{180}$ Löwel H, Döring A, Schneider A, Heier M, Thorand B, Meisinger C, für die MONICA/KORA-Studiengruppe. The MONICA Augsburg surveys basis for prospective cohort studies. Gesundheitswesen 2005; $67 \mathrm{S1}$ : S13-S18

${ }^{181}$ Löwel H, Engel S, Hörmann A, Gostomzyk J, Bolte HD, Keil U. Akuter Herzinfarkt und plötzlicher Herztod aus epidemiologischer Sicht. Intensivmed Prax 1999; 36: 652 - 661

182 Löwel H, Feller G, Kigele U, Lewis M, Stiller H. Stellenwert von kardiovaskulären Risikofaktoren in der ambulanten Praxis: Ergebnisse der Augsburger Ärztebefragung 1989/1990. Münch Med Wochenschr 1991; 133: 549-553

183 Löwel H, Heier M, Schneider A, Gösele U, Meisinger C. Hormontherapie (II). Vergleiche sind zulässig: Deutsche Einnehmerinnen sind mit den Teilnehmerinnen der WHI-Studie hinsichtlich des kardiovaskulären Risikoprofils weitgehend identisch. Ergebnisse aus dem KORASurvey 2000. Dtsch Ärztebl 2003; 40: 2561 - 2562

${ }^{184}$ Löwel H, Herman B, Lewis M, Holtz H, Quietzsch D, Hörmann A, Greiser E, Voigt G, Keil U. Registration methods and estimates of morbidity and mortality of acute myocardial infarction: Results from East and West Germany. Ann Epidemiol 1993; 3 (Suppl. 5): 69-78

${ }^{185}$ Löwel H, Hörmann A, Engel S. Frauen und Herzinfarkt. Besonderheiten im Vergleich zu Männern. Internist Prax 1998; 38: 1 - 9 (und tägl prax 1998; 39: 1-9)

186 Löwel H, Hörmann A, Gostomzyk J, Keil U. Epidemiologie des plötzlichen Herztodes: Was hat sich verändert? Ergebnisse des MONICA Augsburg Herzinfarktregisters 1985-1995. Herzschr Elektrophys 1999; 10 (suppl 2): 1 - 7

187 Löwel H, Hörmann A, Lewis M, Krawietz W, Bolte HD. Thrombolysetherapie und Koronarangiographie bei akutem Myokardinfarkt in der Region Augsburg: Ergebnisse des Augsburger Herzinfarktregisters 1985 - 1987. Z Kardiol 1990; 79: 580-585

${ }^{188}$ Löwel H, Keil U, Koenig W, Hörmann A, Lewis M, Bolte HD, Gostomzyk JG. Morbidity and mortality of myocardial infarction in the MONICA study area Augsburg in 1985. Soz Praventivmed 1988; 33 : $17-21$

189 Löwel H, Koenig W, Engel S, Hörmann A, Keil U. The impact of diabetes mellitus on survival after myocardial infarction: can it be modified by drug treatment? Results of a population-based myocardial infarction register follow-up study. Diabetologia 2000; 43: 218-226

${ }^{190}$ Löwel H, Lewis M, Gostomzyk JG, Keil U. Bevölkerungsbezogenes Herzinfarktregister in der Region Augsburg: Möglichkeiten und Einschränkungen. Soz Praventivmed 1991; 36: 159-165

191 Löwel H, Lewis M, Härtel U, Hörmann A. Herzinfarkt-Patienten ein Jahr nach dem Ereignis. Ergebnisse des bevölkerungsbezogenen Augsburger Herzinfarktregisters. Münch Med Wochenschr 1994; 136: $29-34$

192 Löwel H, Lewis M, Hörmann A, Eberle E, Bolte HD, Gostomzyk JG, Keil U. Morbidität und Mortalität an akutem Herzinfarkt. Daten aus der MONICA-Studienregion Augsburg (1985-1988). Münch Med Wochenschr 1991; 133: 20-25

193 Löwel H, Lewis M, Hörmann A, Eberle E, Keil U. Morbidity and mortality of myocardial infarction in the Augsburg MONICA study area in 1885, 1986 and 1987. Rev Epidemiol Sante Publique 1990; 38 : $411-417$

${ }^{194}$ Löwel H, Lewis M, Hörmann A, Gostomzyk JG, Keil U. Todesursachenstatistik. Wie sicher ist die Angabe „ischämische Herzerkrankung“? Ergebnisse des MONICA-Augsburg Herzinfarktregisters 1985 bis 1988. Dtsch Ärztebl 1991; 88: C1495 - C1499

195 Löwel H, Lewis M, Hörmann A, Keil U. Case finding, data quality aspects and comparability of myocardial infarction registers: Results of a south german register study. J Clin Epidemiol 1991; 44: 249-260

196 Löwel H, Lewis M, Hörmann A. Prognostische Bedeutung der Prähospitalphase beim akuten Myokardinfarkt: Ergebnisse des Augsburger Herzinfarktregisters 1985-1988. Dtsch Med Wochenschr 1991; 116: 729 - 733; auch: Dtsch Med Wochenschr (japanische Ausgabe) 1991; 13: $653-657$

197 Löwel H, Lewis M, Keil U, Hörmann A, Bolte HD, Willich S, Gostomzyk JG. Zeitliche Trends von Herzinfarktmorbidität, -mortalität, 28-TageLetalität und medizinischer Versorgung: Ergebnisse des Augsburger Herzinfarktregisters von 1985 bis 1992. Z Kardiol 1995; 84: 596- 605

198 Löwel H, Lewis M, Keil U, Koenig W, Hörmann A, Bolte HD, Gostomzyk JG. Zur Herzinfarktsituation in einer süddeutschen Bevölkerung: Ergebnisse des Augsburger Herzinfarkt-Registers 1985. Z Kardiol 1988; 77: 481 - 489

${ }^{199}$ Löwel H, Meisinger C, Heier M, Hörmann A, Kuch B, Gostomzyk J, Koenig W. Geschlechtsspezifische Trends von plötzlichem Herztod und akutem Herzinfarkt: Ergebnisse des bevölkerungsbasierten KORA/MONICA Augsburg Herzinfarkt-Registers 1985 bis 1998. Dtsch Med Wochenschr 2002; 127: 2311 -2316

${ }^{200}$ Löwel H, Meisinger C, Heier M, Hörmann A. The Population-based Acute Myocardial Infarction (AMI) Registry of the MONICA/KORA Study Region of Augsburg. Gesundheitswesen 2005; 67 S1: S31 - S37

${ }^{201}$ Löwel H, Meisinger C, Schneider A, Trentinaglia I, Heier M, Hörmann A, Kuch B, Thorand B. Diabetiker als Hochrisikogruppe für Herzinfarkt. Ergebnisse der MONICA-Augsburg-Studien. Cardio Vasc 2001; 1: 14-25

${ }^{202}$ Löwel H, Meisinger C, Thorand B. Diabetes mellitus - eine Gefahr für das Herz? Gesund in Bayern. LZG Info 1999; November/Dezember: 6-7

${ }^{203}$ Löwel H, Müller J, Heier M, Thorand B, Meisinger C, Hörmann A. Frauen und koronare Herzkrankheit: epidemiologische Besonderheiten im Vergleich zu Männern. In: Brachmann J, Medau HJ (Hrsg). Die koronare Herzkrankheit der Frau. Darmstadt: Steinkopff Verlag, 2002: $19-36 \mathrm{~d}$

${ }^{204}$ Löwel H, Stieber J, Koenig W, Thorand B, Hörmann A, Gostomzyk J, Keil U. Das Diabetes-bedingte Herzinfarktrisiko in einer süddeutschen Bevölkerung: Ergebnisse der MONICA-Augsburg-Studien 1985 - 1994. Diab Stoffw 1999; 8: 11 - 21

${ }^{205}$ Löwel H, Thorand B, Stieber J, Keil U. Epidemiologie der Hypertonie (nach den WHO-/ISH-Richtlinien 1999). Ergebnisse der MONICA(Augsburg-)Studien 1984/85 und 1994/95. Synopsis 1999; 3: 7-11

206 Löwel H, Trentinaglia I, Heier M, Hörmann A. Der prähospitale Herzstillstand - eine Herausforderung an die Notfallmedizin. Ergebnisse aus dem Augsburger Herzinfarktregister. In: Arntz HR, Tebbe U, Gulba DC (Hrsg). Notfallbehandlung des akuten Koronarsyndroms. Prä- und intrahospitale Diagnostik und Therapie. Stuttgart: Springer Verlag, 2001: $1-13$

${ }^{207}$ Löwel H. Der akute Herzinfarkt: Gefahren und Chancen. Ergebnisse aus dem MONICA Herzinfarktregister 1985/95. Gesund in Bayern. LZG Info 1999; Mai/Juni: 6-7

${ }^{208}$ Löwel H. Frauenspezifische Besonderheiten der koronaren Herzkrankheit. Überarbeiteter und erweiterter Beitrag zum Podiumsgespräch Schlagen Frauenherzen anders? In: Kulturverein Schloß Goldegg (Hrsg). Unser Herz - eine Pumpe mit Gefühl? 16. Goldegger Dialoge. Goldegg (Österreich): Eigenverlag, 1998: 49-64

${ }^{209}$ Löwel H. Herzinfarktmorbidität und Diabetes mellitus. Aufgaben und Ergebnisse des Augsburger Herzinfarktregisters. Klinikarzt 2000; 29: $42-45$

${ }^{210}$ Löwel H. Langzeitprognose nach Herzinfarkt: Ergebnisse des Augsburger Herzinfarktregisters. Der Bay Int 1997; 17: 78-80

${ }^{211}$ Luchner A, Bröckel U, Muscholl M, Hense HW, Döring A, Riegger G, Schunkert H. Gender-specific differences of cardiac remodeling in subjects with left ventricular dysfunction: a population-based study. Cardiovasc Res 2002; 53: 720-727

212 Luchner A, Burnett JC Jr, Jougasaki M, Hense HW, Heid IM, Muders F, Riegger GA, Schunkert H. Evaluation of brain natriuretic peptide as marker of left ventricular dysfunction and hypertrophy in the population. J Hypertens 2000; 18: 1121 - 1128 
${ }^{213}$ Luchner A, Burnett JC Jr, Jougasaki M, Hense HW, Riegger GA, Schunkert $\mathrm{H}$. Augmentation of the cardiac natriuretic peptides by beta-receptor antagonism: evidence from a population-based study. J Am Coll Cardiol 1998; 32: 1839-1844

${ }^{214}$ Luchner A, Hengstenberg C, Löwel H, Trawinski J, Baumann M, Riegger G, Schunkert H, Holmer S. N-Terminal Pro-Brain Natriuretic Peptide After Myocardial Infarction. A Marker Of Cardio-Renal Function. Hypertension 2002; 39: 99-104

${ }^{215}$ Mähönen M, McElduff P, Dobson AJ, Kuulasmaa K, Evans A, for the WHO MONICA Project. Current smoking and the risk of nonfatal myocardial infarction in the WHO MONICA Project populations. Tob Control 2004; 13: $244-250$

${ }^{216}$ Manstetten A, Wildner M. Computer-assistierte Datenerfassung: Fragebogendesign, Schulung und qualitätssichernde Massnahmen. Zeitschrift für Gesundheitswissenschaft 2000; 8: 114-126

217 Marquardt M, Döring A, Stieber J, Filipiak B, Löwel H, Holle R. Inkonsistenzen von Probandenangaben bei Wiederholungsbefragungen in Gesundheitssurveys. Erfahrungen aus dem MONICA-Augsburg-Projekt. In Messung soziodemographischer Merkmale in der Epidemiologie. RKI-Schriften 1998; 1: 87-94

218 Marques-Vidal P, Ferrieres J, Metzger MH, Cambou JP, Filipiak B, Löwel $\mathrm{H}$, Keil $\mathrm{U}$. Trends in coronary heart disease morbidity and mortality and acute coronary care and case fatality from 1985-1989 in southern Germany and south-western France. Results from the MONICA Projects in Augsburg and Toulouse. Eur Heart J 1997; 18: $816-821$

${ }^{219}$ Marti B, Rickenbach M, Keil U, Stieber J, Greiser E, Herman B, Heinemann L, Assmann A, Schädlich H, Nüssel E, Östör-Lamm E, Gutzwiller F. Variation in coronary risk factor levels of men and women between German-speaking MONICA centres. Rev Epidemiol Sante Publique 1990; 38: 479-486

${ }^{220}$ Marx FP, Holzmann C, Strauss KM, Li L, Eberhard O, Cookson M, Farrer MR, Engelender S, Ross C, Berger K, Schöls L, Schulz JB, Riess O, Krüger R. Identification and functional characterisation of a novel R621C mutation in the synphilin-1 gene in Parkinson's disease. Hum Mol Genet 2003; 12: 1223-1231

${ }^{221}$ Maziak W, Keil U, Döring A, Hense HW. Determinants of poor hypertension mamagement in the community. J Hum Hypertens 2003; 17: $215-217$

222 McGauran N, Berger K, Robra BP. Subjektiver Hilfebedarf und objektivierendes Geriatrisches Assessment - die Halberstädter Gerontologische Studie und die Augsburger Senioren Studie im Vergleich. Z Gerontol Geriatr 2001; 35: 60-69

${ }^{223}$ Meisinger C, Döring A, Heier M, Thorand B, Löwel H, for the WHO MONICA Project. Type 2 Diabetes mellitus in Augsburg - an epidemiological overview. Gesundheitswesen 2005; 67 S1: S103 -S104

224 Meisinger C, Heier M, Döring A, Löwel H, for the WHO MONICA Project. Prevalence of known diabetes mellitus and antidiabetic therapy between 1984/85 and 1999/2001 in Southern Germany. Diabetes Care 2004; 27: 2985-2987

225 Meisinger C, Heier M, Löwel H. Sleep disturbance as a predictor for type 2 diabetes mellitus in men and women from the general population. The MONICA/KORA Augsburg Cohort Study. Diabetologia 2005; 48: 235-241

${ }^{226}$ Meisinger C, Heier M, Löwel $\mathrm{H}$. The relationship between body weight and health care among German women. Results of the MONICA Augsburg Survey 1994/95. Obesity Research 2004; 12: $1473-1480$

${ }^{227}$ Meisinger C, Loewel H, Thorand B, Doering A. Leisure time physical activity and the risk of type 2 diabetes mellitus in men and women from the general population. The MONICA/KORA Augsburg Cohort Study. Diabetologia 2005; 48 (1): 27-34

228 Meisinger C, Löwel H, Mraz W, König W. Prognostic value of apolipoprotein $\mathrm{B}$ and $\mathrm{A}-\mathrm{I}$ in the prediction of myocardial infarction in middleaged men and women: results from the MONICA/KORA Augsburg cohort study. Eur Heart J 2005; 26: 1 -8

${ }^{229}$ Meisinger C, Schuler A, Löwel H, for the WHO MONICA Project. Postal questionnaire identifies hospitalizations for self-reported acute myocardial infarction. J Clin Epidemiol 2004; 57: 989-992

${ }^{230}$ Meisinger C, Thorand B, Schneider A, Stieber J, Döring A, Löwel H. Sex Differences in risk factors for incident type 2 diabetes mellitus. Arch Intern Med 2002; 162: $82-89$
Meisinger C, Thorand B, Schneider A, Stieber J, Döring A, Tietze M, Löwel H. Kardiovaskuläre Risikofaktoren und Diabetesinzidenz: Ergebnisse der MONICA-Augsburg-Kohortenstudie 1984-1998. Diabetes und Stoffwechsel 2001; 10: 3-11

232 Meisinger C, Wildner M, Döring A, Sangha O. Validität und Reliabilität von Probandenangaben zu Frakturen. Soz Praventimed 2000; 45: $203-207$

${ }^{233}$ Meisinger C, Wildner M, Stieber J, Heier M, Sangha O, Döring A. Epidemiologie der Extremitätenfrakturen. Ergebnisse des MONICA-Surveys 1994/1995 in der Region Augsburg. Orthopäde 2002; 31: 92 - 99

${ }^{234}$ Merkl J, Klemm E, Wichmann HE, Ring J, Schäfer T. Heuschnupfen bei Partnern. Allergo J 2001; 10: 320-323

${ }^{235}$ Merlo J, Asplund K, Lynch J, Rastam L, Dobson A, for the World Health Organization MONICA Project. Population effects on individual systolic blood pressure: a multilevel analysis of the world health organization MONICA Project. Am J Epidemiol 2004; 159: 1168 - 1179

${ }^{236}$ Metzger MH, Engel S, Hengstenberg C, Schneider A, Stieber J, Döring A, Thorand B, Holmer S, Löwel H. Do siblings of myocardial infarction patients have a specific management of hypertension? J Hum Hypertens 2002; 16: $67-74$

${ }^{237}$ Mielck A, Reisig V, Rathmann W, for the KORA Study Group. Health inequalities among persons with type 2 diabetes: The example of intermittent claudication. Gesundheitswesen 2005; 67 S1: S137-S143

${ }^{238}$ Mönnichs G, v Lengerke T. Unzufriedenheit mit dem eigenen Gewicht nach Reduktionsdiät bei Frauen und Männern: Ergebnisse des KORASurvey 2000. Z Gesundheitspsychol 2004; 12: 116-130

${ }^{239}$ Mostafazadeh A, Herder C, Haastert B, Hanifi-Moghaddam P, Schloot N, Koenig W, Illig T, Thorand B, Holle R, Eslami M-B, Kolb H, and members of the KORA Group. Association of humoral immunity to human Hsp60 with metabolic and inflammatory parameters and with the IL- 6 gene polymorphism C-174G in patients with type 2 diabetes and controls. Hormone Metab Res 2005; 37 (4): 257-263

${ }^{240}$ Müller JE, Döring A, Heier M, Löwel H. Prevalence and determinants of hormone replacement therapy in German women 1984-1995. Maturitas 2002; 43: 95-104

${ }^{241}$ Müller S, Martin S, Koenig W, Hanifi-Moghaddam P, Rathmann W, Haastert B, Giani G, Illig T, Thorand B, Kolb H. Impaired glucose tolerance is associated with increased serum concentrations of interleukin 6 and co-regulated acute-phase proteins but not TNF- $\alpha$ or its receptors. Diabetologia 2002; 45: 805-812

242 Müller-Nordhorn J, Arntz HR, Löwel H, Willich SN. The epidemiology of sudden cardiac death. Herzschr Elektrophys 2001; 12: 3-8

${ }^{243}$ Muscholl MW, Hense HW, Bröckel U, Döring A, Riegger GAJ, Schunkert $\mathrm{H}$. Changes in left ventricular structure and function in patients with white coat hypertension: cross sectional survey. BMJ 1998; 317 $565-570$

${ }^{244}$ Muscholl MW, Schunkert H, Muders F, Elsner D, Kuch B, Hense HW, Riegger GA. Neurohormonal activity and left ventricular geometry in patients with essential arterial hypertension. Am Heart J 1998; 135: $58-66$

245 Papke K, Janßen C. Tagebücher als Befragungsinstrument im Kontext des KORA-Projektes „Krankheitskosten von Asthma und Allergien“. Zeitschrift für Gesundheitswissenschaften 2000; 8: 149-157

${ }^{246}$ Perz S, Gehring J, Holle R, Küfner R, Mielck A. Factors affecting the sensitivity of computerized ECG analysis in identifying previous myocardial infarction. Comput Cardiol 1999; 26: 671 - 674

${ }^{247}$ Perz S, Gehring J, Hörmann A, Küfner R, Mielck A. Zur Bedeutung technischer und medizinischer Faktoren bei der Erkennung von Myokardinfarkten durch die automatische EKG-Analyse. Biomedizinische Technik 2000; 45 (Ergänzungsband 2): 70-75

${ }^{248}$ Perz S, Küfner R, Meisinger C, Ziegler D, Englmeier KH, and members of the KORA Group. The Effect of Different QT interval Corrections for Heart Rate on the QT Distributions in Diabetics and Non-Diabetic Subjects. Beiträge zur 38. Jahrestagung der Deutschen Gesellschaft für Biomedizinische Technik im VDE BMT 2004, TU Ilmenau, 22. - 24.9.2004. Biomedizinische Technik 2004; 49 (Ergänzungsband 2): $296-297$

${ }^{249}$ Perz S, Peters A, Döring A, Gehring J, Küfner R, Englmeier K-H. Computerized ECG analysis identifies adverse health effects of air pollutants. In: Blobel B, Gell G, Hildebrand C, Engelbrecht R (Hrsg). Contribution of Medical Informatics to Health - Proceedings of the European Federation for Medical Informatics Special Topics Conference, Munich, Germany, June 13-16, 2004. Berlin: Akademische Verlagsgesellschaft Aka GmbH, 2004: 95-97 
${ }^{250}$ Perz S, Pfeufer A, Holle R, Hinterseer M, Küfner R, Englmeier $\mathrm{KH}$, Wichmann HE, Kääb S, for the KORA Study Group. Does computerized ECG analysis provide sufficiently consistent QT interval estimates for genetic research? In: Jan J, Kozumplik J, Provaznik I (Hrsg). Analysis of Biomedical Signals and Images - Proceedings of the 17th International EURASIP Conference Biosignal 2004, Brno, Czech Republic, June 23 - 25, 2004 Vutium Press, 2004: 47-49

${ }^{251}$ Peters A, Döring A, Koenig W. Increased plasma viscosity during an air pollution episode: a link to mortality? Lancet 1997; 349: $1582-1587$

252 Peters A, Fröhlich M, Döring A, Immervoll T, Wichmann HW, Hutchinson LW, Pepys MB, Koenig W. Particulate air pollution is associated with an acute phase response in men. Eur Heart J 2001; 22: $1198-1204$

253 Peters A, Perz S, Döring A, Koenig W, Wichmann HE. Increases in heart rate during an air pollution episode. Am J Epidemiol 1999; 150: $1094-1098$

254 Peters A, von Klot S, Heier M, Trentinaglia I, Hörmann A, Wichmann $\mathrm{HE}$ et al. Exposure to traffic and the onset of myocardial infarction. $\mathrm{N}$ Engl J Med 2004; 351: 1721 - 1730

255 Peters A, für die MONICA/KORA-Studiengruppe. Partikel in der Außenluft erhöhen das Risiko für Herzkreislauferkrankungen. Ambient particles increase the risk of cardiovascular diseases. Gesundheitswesen 2005; 67 S1: S79-S87

256 Rahner N, Holzmann C, Krüger R, Schöls L, Berger K, Riess O. The neurofilament $\mathrm{L}$ gene is not a genetic factor of sporadic and familial Parkinson's disease. Brain Res 2002; 951: 82 - 86

${ }^{257}$ Rathmann W, Giani G, Mielck A. Cardiovascular risk factors in newly diagnosed abnormal glucose tolerance: comparison of 1997 ADA and 1985 WHO criteria (letter). Diabetologia 1999; 42: 1268 - 1269

258 Rathmann W, Haastert B, Icks A, Giani G, Holle R, Meisinger C, Mielck A and KORA Study Group. Association of socioeconomic status with undiagnosed diabetes mellitus and impaired glucose tolerance in a population-based sample. The KORA Survey 2000 (im Druck)

${ }^{259}$ Rathmann W, Haastert B, Icks A, Herder C, Kolb H, Holle R, Mielck A, Meisinger C, Wichmann HE, Giani G. The Diabetes Epidemic in the Elderly Population in Western Europe: Data from Population-Based Studies. Gesundheitswesen 2005; 67 S1: S110-S114

${ }^{260}$ Rathmann W, Haastert B, Icks A, Löwel H, Meisinger C, Holle R, Giani G. High prevalence of undiagnosed diabetes mellitus in Southern Germany: Target populations for efficient screening. The KORA survey 2000. Diabetologia 2003; 46: $182-189$

${ }^{261}$ Rathmann W, Icks A, Haastert B, Giani G, Löwel H, Mielck A. Undiagnosed diabetes mellitus among patients with prior myocardial infarction. Z Kardiol 2002; 91: 620-625

${ }^{262}$ Rathmann W, Martin S, Haastert B, Icks A, Holle R, Löwel H, Giani G and KORA Study Group. Performance of screening questionnaires and risk scores for undiagnosed diabetes: the KORA Survey 2000. Arch Intern Med 2005; 165 (4): 436-441

263 Resch A, Schlipköter U, Crispin A, Behrendt H, Heinrich H, Wichmann HE, Ring J, Schäfer T and the KORA study group. Atopic disease and its determinants - a focus on the potential role of childhood infection. Clin Exp Allergy 2004; 34: 1184-1191

${ }^{264}$ Riehle A, Ring J, Wichmann HE, Schäfer T. Alternativmedizin und Allergien: Lebenszufriedenheit, Kontrollüberzeugung zu Gesundheit und Krankheit und Lebensqualität. Allergo J 2002; 11: 447 - 451

${ }^{265}$ Riemenschneider M, Klopp N, Xiang W, Wagenpfeil S, Vollmert C, Müller U, Förstl H, Illig T, Kretzschmar H, Kurz A. Prion protein codon 129 polymorphism and risk of Alzheimer disease. Neurology 2004; 63: $364-366$

${ }^{266}$ Rothdach AJ, Trenkwalder C, Haberstock J, Keil U, Berger K. Prevalence and risk factors of the Restless Legs Syndrome in an elderly population - The MEMO Study. Neurology 2000; 54: 1064-1068

267 Schaeffler V, Döring A, Winkler G, Keil U. Erhebung der Alkoholaufnahme: Vergleich verschiedener Methoden. Ernährungs-Umschau 1991; 38: 490-494

${ }^{268}$ Schaeffler V, Döring A, Winkler G, Keil U. Trends in food consumption in a South German population from 1984/85 to 1989/90: Results from the WHO MONICA Project Augsburg. Ann Nutr Metab 1996; 40: $129-136$

${ }^{269}$ Schäfer R, Ruhdorfer R, Weigl L, Wessner D, Heinrich J, Döring A, Wichmann HE, Ring J. Intake of unsaturated fatty acids and HDL cholesterol levels are associated with manifestations of atopy in adults. Clin Exp Allergy 2003; 33: 1360-1367

Schäfer T, Böhler E, Ruhdorfer S, Weigl L, Wessner D, Filipiak B, Wichmann HE, Ring J. Epidemiology of contact allergy in adults. Allergy 2001; 56: $1192-1196$

${ }^{271}$ Schäfer T, Böhler E, Ruhdorfer S, Weigl L, Wessner D, Heinrich J, Filipiak B, Wichmann HE, Ring J. Epidemiology of food allergy/food intolerance in adults: associations with other manifestations of atopy. $\mathrm{Al}-$ lergy 2001; 56: 1172 - 1179

272 Schäfer T, Böhler E, Wichmann HE, Filipiak B, Ring J. Die KORA-Allergie-Studie: Ergebnisse der Epikutantestung. Allergo J 2000; 9: $475-477$

${ }^{273}$ Schäfer T, Heinrich J, Böhler E, Klemm E, Merkl J, Ruhdorfer S, Weigl L, Wessner D, Wichmann HE, Ring J, für die MONICA/KORA-Studiengruppe. Allergien bei Erwachsenen. Gesundheitswesen 2005; 67 S1: S187-S192

${ }^{274}$ Schäfer T, Merkl J, Klemm E, Wichmann HE, Ring J, KORA Study group. Does my partner cause my allergy? Allergy 2004; 59: 781 - 785

275 Schäfer T, Riehle A, Wichmann HE, Ring J. Alternative medicine and allergies: Life satisfaction, Health locus of control, and Quality of Life. J Psychosom Res 2003; 55: 543 - 546

276 Schäfer T, Riehle A, Wichmann HE, Ring J. Alternative medicine in allergies - prevalence, patterns of use, and costs. Allergy 2002; 57: $694-700$

277 Schäfer T, Ruhdorfer S, Weigl L, Wessner D, Heinrich J, Wichmann HE, Ring J. School education and allergic sensitisation in adults. Allergy 2001; 56: 1206 - 1210

${ }^{278}$ Schäfer T. Epidemiologie of complementary alternative medicine for asthma and allergy in Europe and Germany. Ann Allergy Asthma Immunol 2004; 93: 5-10

279 Schedel M, Carr D, Klopp N, Woitsch B, Illig T, Stachel D, Schmid I, Fritzsch C, Weiland SK, Mutius Ev, Kabesch M. A signal transducer and activator of transcription 6 haplotype influences the regulation of serum IgE levels. J Allergy Clin Immunol 2004; 114: 1100-1105

${ }^{280}$ Schellhorn B, Döring A, Stieber J. Zufuhr an Vitaminen und Mineralstoffen aus Nahrungsergänzungspräparaten in der MONICA-Querschnittsstudie 1994/95 der Studienregion Augsburg. Z Ernährungswiss 1998; 37: 198-206

${ }^{281}$ Schenkirsch G, Heier M, Stieber J, Löwel H. Trends in der Schmerzmitteleinnahme über einen Zeitraum von 10 Jahren (1984 bis 1995). Ergebnisse der drei MONICA-Augsburg-Surveys. Dtsch med Wochenschr 2001; 126: 643-648

${ }^{282}$ Schmidt R, Launer L, Nilsson LG, Pajak A, Sans S, Berger K, Breteler MM, de Ridder M, Dufouil C, Giampaoli S, Hofman A, for the CASCADE Consortium. MRI Of The Brain In Diabetes Mellitus: The Cardiovascular Determinants Of Dementia (CASCADE) Study. Diabetes 2004; 53: 687-692

${ }^{283}$ Schmidt WP, Roesler A, Kretzschmar K, Ladwig KH, Junker R, Berger K. Functional and Cognitive Consequences of Silent Stroke on Brain MRI in an Elderly Population. J Am Geriatr Soc 2004; 52: $1045-1050$

${ }^{284}$ Schulte T, Bohringer S, Schols L, Muller T, Fischer C, Riess O, Przuntek $\mathrm{H}$, Berger K, Epplen JT, Kruger R. Modulation of disease risk according to a cathepsin $\mathrm{D} /$ apolipoprotein E genotype in Parkinson's disease. J Neural Transm 2003; 110: 749-755

285 Schulte T, Schöls L, Müller T, Woitalla D, Berger K, Krüger R. Polymorphisms in the interleukin- 1 alpha and beta genes and the risk for Parkinson's disease. Neurosci Lett 2002; 326: 70-72

${ }^{286}$ Schulz H, Harder V, Ibald-Mulli A, Khandoga A, Koenig W, Krombach F, Radykewicz R, Stampfl A, Thorand B, Peters A. Cardiovascular effects of fine and ultrafine particles. J Aerosol Med (im Druck)

287 Schunkert H, Bröckel U, Hengstenberg C, Luchner A, Muscholl MW, Kurzidim K, Kuch B, Döring A, Riegger GAJ, Hense HW. Familial predisposition of left ventricular hypertrophy. J Am Coll Cardiol 1999; 33: $1685-1691$

288 Schunkert H, Danser AH, Hense HW, Derkx FH, Kurzinger S, Riegger GA. Effects of estrogen replacement therapy on the renin angiotensin system in postmenopausal women. Circulation 1997; 95: 39-45

289 Schunkert H, Danser AHJ, Hense HW, Derks FHM, Kürzinger S, Riegger GAJ. Effects of estrogen replacement therapy of the renin-angiotensin system in postmenopausal women. Circulation 1997; 95: $39-45$

290 Schunkert H, Döring A, Kuch B, Holmer S, Luchner A, Muscholl M, Fischer M, Hengstenberg C, Riegger GAJ, Hense HW. Cardiovascular phenotypes and functional parameters in the general population results of the MONICA/KORA studies. Gesundheitswesen 2005; 67 S1: S74-S78 
${ }^{291}$ Schunkert H, Hengstenberg C, Holmer SR, Bröckel U, Luchner A, Muscholl MW, Kürzinger S, Döring A, Hense HW, Riegger GAJ. Lack of association between a polymorphism of the aldosterone synthase gene and left ventricular structure. Circulation 1999; 99: 2255-2260

292 Schunkert H, Hense HW, Andus T, Riegger GA, Straub RH. Relation between dehydroepiandrosterone sulfate and blood pressure levels in a population-based sample. Am J Hypertens 1999; 12 (11): $1140-1143$

${ }^{293}$ Schunkert H, Hense HW, Brockel U, Luchner A, Muscholl M, Holmer SR, Danser AH, Mayer B, Riegger GA. Differential effects of antihypertensive drugs on neurohormonal activation: insights from a population-based sample. J Int Med 1998; 244: 109-119

${ }^{294}$ Schunkert H, Hense HW, Döring A, Riegger GAJ, Siffert W. Association between a polymorphism in the protein beta3 subunit gene and lower renin and elevated diastolic blood pressure levels. Hypertension 1998; 32: $510-513$

${ }^{295}$ Schunkert H, Hense HW, Gimenez-Roqueplo AP, Stieber J, Keil U, Riegger GAJ, Jeunemaitre X. The angiotensinogen T235 variant and the use of antihypertensive drugs in a population-based cohort. Hypertension 1997; 29: $628-633$

${ }^{296}$ Schunkert H, Hense HW, Holmer SR, Stender M, Perz S, Keil U, Lorell $\mathrm{BH}$, Riegger GAJ. Association between a deletion polymorphism of the angiotensin-converting-enzyme gene and left ventricular hypertrophy. N Engl J Med 1994; 330: 1634 - 1638

297 Schunkert H, Hense HW, Muscholl M, Luchner A, Kurzinger S, Danser $\mathrm{AH}$, Riegger GA. Associations between circulating components of the renin-angiotensin-aldosterone system and left ventricular mass. Heart 1997; 77: $24-31$

${ }^{298}$ Schunkert H, Hense HW, Muscholl M, Luchner A, Kürzinger S, Danser $\mathrm{AH}$, Riegger GAJ. Association between circulating components of renin-angiotensin-aldosterone system and left ventricular mass. Heart 1997; 77: $24-31$

${ }^{299}$ Schunkert H, Hense HW, Muscholl M, Luchner A, Riegger GA. Association of angiotensin converting enzyme activity and arterial blood pressure in a population-based sample. J Hypertens 1996; 14: $571-575$

${ }^{300}$ Schunkert H, Koenig W, Bröckel U, Muscholl M, Döring A, Riegger GAJ, Hense HW. Hematocrit levels profoundly affects the pattern of left ventricular diastolic filling as assessed by Doppler echocardiography. J Hypertens 2000; 18: 1483 - 1489

${ }^{301}$ Sedlacek K, Fischer M, Erdmann J, Hengstenberg C, Holmer S, Kurzinger S, Muscholl M, Luchner A, Riegger GA, Hense HW, Schunkert H. Relation of the $G$ protein beta3-subunit polymorphism with left ventricle structure and function. Hypertension 2002; 40: 162 - 167

${ }^{302}$ Sell K, Gedrich K, Fischer B, Döring A die KORA-Studiengruppe. Trends im Ernährungsverhalten in der Region Augsburg. Ergebnisse der MONICA-/KORA-Studien 1984 bis 2001. Ernährungs-Umschau 2003; 50: 208 - 213

303 Shahar E, Lewis M, Keil U, McGovern PG, Löwel H, Luepker RV. Hospital care and survival of acute myocardial infarction patients in Minnesota and southern Germany: a comparative study. Coron Artery Dis 1996; 7: $467-473$

${ }^{304}$ Siffert W, Rosskopf D, Siffert G, Busch S, Moritz A, Erbel R, Sharma AM, Ritz E, Wichmann HE, Jakobs KH, Horsthemke B. Association of a human G-protein $B 3$ subunit variant with hypertension. Nat Genet 1998; $18: 45-48$

${ }^{305}$ Silventoinen K, Sans S, Tolonen H, Monterde D, Kuulasmaa K, Kesteloot H, Tuomilehto J, for the WHO MONICA Project. Trends in obesity and energy supply in the WHO MONICA Project. Int J Obes 2004; 28: $710-718$

${ }^{306}$ Stender M, Döring A, Hense HW, Schlichtherle S, M'Harzi S, Keil U. Vergleich zweier Methoden zur Erhebung der körperlichen Aktivität. Soz Praventivmed 1991; 36: $176-183$

307 Stender M, Hense HW, Döring A, Keil U. Physical activity at work and cardiovascular disease risk: Results from the MONICA-Augsburg Study. Int J Epidemiol 1993; 22: 644-650

${ }^{308}$ Stieber J, Härtel U, Heller WD, Keil U, Gostomzyk JG. Smoking habits and attitude to smoking in the study population of the MONICA project Augsburg. Soz Praventivmed 1988; 33: 22-26

${ }^{309}$ Stieber J, Hense HW, Döring A, Filipiak-Pittroff B, Tietze M, Gostomzyk JG, Keil U. Kardiovaskuläres Risikofaktorenprofil: Verlaufsdaten aus der MONICA-Studienregion Augsburg (1984/85 vs. 1989/90). Münch Med Wochenschr 1991; 133: 370-375
Straub RH, Hense HW, Andus T, Scholmerich J, Riegger GA, Schunkert $\mathrm{H}$. Hormone replacement therapy and interrelation between serum interleukin 6 and body mass index in postmenopausal women: a population-based study. J Clin Endocrinol Metab 2000; 85: 1340-1344

311 Sykes DH, Härtel U, Gostautas A, Evans AE. The Framingham type A behavior pattern and coronary heart disease in three countries: A cross-cultural comparison. Int J Epidemiol 1992; 21: 1081 - 1089

312 Tennis P. Drug utilization by the 30-64 year-old people in two cities in the Federal Republic of Germany in 1984. Eur J Clin Pharmacol 1990; 38: $447-452$

313 The WHO MONICA Project. Geographical variation in the major risk factors of coronary heart disease in men and women aged $35-64$ years. World Health Stat Q 1988; 41: $115-140$

314 Thorand B, Liese AD, Metzger MH, Reitmeir P, Schneider A, Löwel H. Can inaccuracy of reported parental history of diabetes explain the maternal transmission hypothesis for diabetes? Int J Epidemiol 2001; 30: $1084-1089$

315 Thorand B, Löwel H, Schneider A, Kolb H, Meisinger C, Fröhlich M, Koenig W. C-reactive protein as a predictor for incident diabetes mellitus among middle-aged men. Results from the MONICA Augsburg cohort study, 1984 - 1998. Arch Intern Med 2003; 163: 93 -99

316 Thorand B, Schneider A, Baumert J, Döring A, Marowsky-Köppl M, Heier M, Meisinger C, Löwel H. Fall-Kohorten-Studien: Ein effektives Design zur Untersuchung von Biomarkern als Risikofaktoren für chronische Krankheiten - Darstellung am Beispiel der MONICA/ KORA Augsburg Fall-Kohorten Studie 1984-2002. Gesundheitswesen 2005; 67 S1: S98-S102

317 Ubl A, Berg D, Holzmann C, Krüger R, Berger K, Arzberger T, Bornemann A, Riess 0. 14-3-3 protein is a component of Lewy bodies in Parkinson's disease - Mutation analysis and association studies of 14 - 3- 3 eta. Brain Res Mol Brain Res 2002; 108: 33 - 39

318 Uter W, Ludwig A, Balda BR, Schnuch A, Pfahlberg A, Schäfer T, Wichmann HE, Ring J. The Prevalence of contact allergy differed between population-based and clinic-based data. J Clin Epidemiol 2004; 57 : 627-632

${ }^{319}$ Uter W, Ludwig A, Balda BR, Schnuch A, Schäfer T, Wichmann HE, Ring J. Prävalenz von Kontaktsensibilisierung gegen Allergene der „Standardreihe“ - Vergleich von KORA-Studiendaten mit dem IVDKRegister. Allergo J 2001; 10: 326-328

${ }^{320}$ von Lengerke T, Happich M, Reitmeir P, John J, for the KORA Study Group. Utilization of out- and inpatient health services by obese adults: a populationbased study in the Augsburg region, Germany. Gesundheitswesen 2005; 67 S1: S150-S157

${ }^{321}$ van Dijk EJ, Breteler MMB, Schmidt R, Berger K, Nilsson LG, Oudkerk M, Pajak A, Sans S, de Ridder M, Dufouil C, Fuhrer R, Giampaoli S, Launer LJ, Hofman A, for the CASCADE Consortium. The association between blood pressure, hypertension and cerebral white matter lesions: the CASCADE study. Hypertension 2004; 44: 625-630

322 Weedon M, Schwarz P, Horikawa Y, Iwasaki N; Illig T, Holle R, Rathmann W, Selisko T, Schulze J, Owen K, Evans J, del Bosque-Plata L, Hitman G, Walker M, Levy J, Sampson M, Bell G, McCarthy M, Hattersley A, Frayling T. Meta-analysis confirms a role for Calpain-10 variation in type 2 diabetes susceptibility. Letter to the Editor. Am J Hum Genet 2003; 73: $1208-1212$

${ }^{323}$ Weidinger S, Klopp N, Wagenpfeil S, Rümmler L, Schedel M, Kabesch M, Schäfer T, Darsow U, Jakob T, Behrendt H, Wichmann HE, Ring J, Illig T. Association of a STAT 6 haplotype with elevated serum IgE levels in a population based cohort of white adults. J Med Genet 2004; 41: $658-663$

${ }^{324}$ Wellmann J, Heidrich J, Berger K, Döring A, Heuschmann P, Keil U. Changes in alcohol intake and risk of coronary heart disease and allcause mortality in the MONICA/KORA-Augsburg cohort: 1987-97. Eur J Cardiovasc Prev Rehabil 2004; 11: 48 - 55

325 Weltermann B, Rogalewski A, Homann J, Berger K, Schulte H, Assmann G, Ringelstein EB. Wissen über Schlaganfall in der deutschen Bevölkerung. Dtsch Med Wochenschr 2000; 125: 416-420

${ }^{326}$ Werner A, Reitmeir P, John J. Kassenwechsel und Risikostrukturausgleich in der gesetzlichen Krankenversicherung - empirische Befunde der Kooperativen Gesundheitsforschung in der Region Augsburg (KORA). Gesundheitswesen 2005; 67 S1: S158 - S166

327 WHO MONICA Project prepared by Böthig S. WHO MONICA Project: Objectives and design. Int J Epidmiol 1989; 18 (Suppl. 1): S29-S37 
${ }^{328}$ Dobson A, Evans A, Ferrario M, Kuulasmaa K, Moltchanow VA, Sans S, Tunstall-Pedoe H, Tuomilehto JO, Wedel H, Yarnell J. Changes in estimated coronary risk in the 1980s: data from 38 populations in the WHO MONICA Project. Ann Med 1998; 30: 199-205

329 WHO MONICA Project prepared by Keil U. WHO MONICA Project: Risk factors. Int J Epidemiol 1989; 18 (Suppl. 1): S46-S55

${ }^{330}$ Molarius A, Seidell JC, Kuulasmaa K, Dobson AJ, Sans S, WHO MONICA Project. Smoking and relative body weight: an international perspective from the WHO MONICA Project. J Epidemiol Community Health 1997; $51: 252-260$

${ }^{331}$ Molarius A, Seidell JC, Sans S, Tuomilehto J, Kuulasmaa K, WHO MONICA Project. Waist and hip circumference, and the waist-hip ratio in 19 populations of the WHO MONICA Project. Int J Obes 1999; 23: $116-125$

332 Stewart AW, WHO MONICA Project. Ecological analysis of the association between mortality and major risk factors of cardiovascular disease. Int J Epidemiol 1994; 23: 505-516

333 Tunstall-Pedoe H, Kuulasmaa K, Mähönen M, Tolonen H, Ruokokoski E, Amouyel P, WHO MONICA Project. Contribution of survival and coronary-event rates to changes in coronary heart disease mortality: 10-year results from WHO MONICA Project populations. Lancet 1999; 353: $1547-1557$

334 Tunstall-Pedoe H, Vanuzzo D, Hobbs M, Mähönen M, Cepaitis Z, Kuulasmaa K, Keil U, WHO MONICA Project. Estimation of contribution of changes in coronary care to improving survival, event rates, and coronary heart disease mortality across the WHO MONICA populations. Lancet 2000; 355: $688-700$

335 Tunstall-Pedoe H, WHO MONICA Project. Myocardial infarction and coronary deaths in the World Health Organization MONICA Project. Registration procedures, event rates, and case-fatality rates in 38 populations from 21 countries in four continents. Circulation 1994; 90: $583-612$

${ }^{336}$ Tuomilehto J, WHO MONICA Project. Assessing CHD mortality and morbidity. Int J Epidemiol 1989; 18 (Suppl. 1): S38-S45

337 WHO MONICA Project Principal Investigators. The World Health Organization MONICA Project: A major international collaboration. J Clin Epidemiol 1988; 41: 105 - 114

338 WHO MONICA Project Principle Investigators. Geographic variations in mortality from cardiovascular diseases. World Health Stat Q 1987; 40: $171-184$

${ }^{339}$ WHO MONICA Project. Monitoring trends in cardiovascular disease and risk factors. WHO Chron 1985; 39: 3-5

340 Molarius A, Seidell JC, Sans S, Thuomiletho J, Kuulasmaa K, WHO MONICA Projekt. Educational Level, Relative Body Weight, and Changes in Their Association Over 10 Years: An International Perspective From the WHO MONICA project. Am J Public Health 2000; 90: $1260-1268$

${ }^{341}$ Molarius A, Seidell JC, Sans S, Tuomilehto J, Kuulasmaa Kwith Keil, Döring, Filipiak, Hense, WHO MONICA Projekt. Varying Sensivity of waist action levels to identify subjects with overweight or obesity in 19 populations of the WHO MONICA Projekt. J Clin Epidemiol 1999; 52: $1213-1224$

${ }^{442}$ Wichmann HE, Gieger C, Illig T, for the KORA Study Group. KORA-gen - Resource for population genetics, controls and a broad spectrum of disease phenotypes. Gesundheitswesen 2005; 67 S1: S26-S30

343 Wildner M, Döring A, Meisinger C, Clark DE. Frakturen im höheren Lebensalter - eine Herausforderung für Prävention und Gesundheitsförderung - Ergebnisse der KORA-Frakturstudie Augsburg. Gesundheitswesen 2005; 67 S1: S180-S186

${ }^{344}$ Wildner M, Fischer R, Brunner A. Development of a questionnaire for quantitative assessment in the field of health and human rights. Soc Sci Med 2002; 55: 1725

345 Wildner M, Sangha O, Clark DE, Döring A, Manstetten A. Independent living after fractures in the elderly. Osteoporos Int 2002; 13 : 579-585

${ }^{346}$ Wildner M, Sangha O, Manstetten A, Clark D. Osteoporose und unabhängige Lebensführung nach Frakturen. Public Health Forum 1999; 25: 16

347 Wildner M. Prävention und Knochengesundheit. In: Gostomzyk JG (Hrsg). Innovative Aspekte in der Prävention. München: Schriftenreihe der Landeszentrale für Gesundheit in Bayern e.V, 2002: (Band 7)

348 Wildner M. Unabhängige Lebensführung im Alter durch Knochengesundheit. In: Gostomzyk JG (Hrsg). Aktiv leben - gesund alt werden. Weltgesundheitstag 1999 in Bayern. München: Schriftenreihe der Landeszentrale für Gesundheit in Bayern e.V, 2000: (Band 5)

${ }^{349}$ Wildner M. Osteoporose. Deutsche Med Wochenschr 2001; 126 : A1170-A1172

350 Wildner M. Osteoporose. Deutsche Med Wochenschr Praxis plus 2002; $1: 25-27$

351 Willich SN, Arntz HR, Löwel H, Lewis M, Schröder R, Trimm-Studiengruppe. Aufwachzeitpunkt, Thrombozytenaggregabilität und das Risiko einer akuten koronaren Herzkrankheit. Z Kardiol 1992; 81: 95-99

352 Willich SN, Lewis M, Arntz HR, Löwel H, Schubert F, Stern R, Schröder $\mathrm{R}$, TRIMM-Studiengruppe. Belastungssituation beim akuten Myokardinfarkt: Die Rolle von körperlicher Anstrengung und ungewöhnlichen Lebensereignissen. Z Kardiol 1994; 83: 423-430

${ }^{353}$ Willich SN, Lewis M, Löwel H, Arntz HR, Schubert F, Schröder R. Physical exertion as a trigger of acute myocardial infarction. $N$ Engl J Med 1993; 329: $1684-1690$

${ }^{354}$ Willich SN, Löwel H, Lewis M, Arntz R, Baur R, Winther K, Keil U, Schröder R and Trimm Study Group. Association of wake-time and the onset of myocardial infarction: Triggers and mechanisms of myocardial infarction (TRIMM) Pilot study. Circulation 1991; 84 (Suppl. 6): $62-67$

355 Willich SN, Löwel H, Lewis M, Hörmann A, Arntz HR, Keil U. Weekly variation of acute myocardial infarction - increased monday risk in the working population. Circulation 1994; 90: 87-93

${ }^{356}$ Willich SN, Löwel H, Mey W, Trautner C. Regionale Unterschiede der Herz-Kreislauf-Mortalität in Deutschland. Dtsch Arztebl 1999; 8: A483-A488

357 Winkler G, Brasche S, Döring A, Heinrich J. Dietary intake of middleaged men from an East and a West German city after the German reunification: do differences still exist? Europ J Clin Nutr 1998; 52: $98-103$

358 Winkler G, Döring A, Fischer B. Supplements as a source of micronutrient intake in middle-aged men in southern Germany: Results of the MONICA dietary survey 1994/95. Z Ernährungswiss 1998; 37: $315-318$

359 Winkler G, Döring A, Keil U, Pietinen P, Arveiler D, Cambou JP, Nuttens C, Richard JL, Evans A, McClean R, McCrum E. Comparison of dietary intakes in four selected European populations. Clin Investig 1992; 70: 889-895

360 Winkler G, Döring A, Keil U. Ernährungsverhalten von Männern mittleren Alters der Region Augsburg: Ergebnisse der Ernährungserhebung 1984/85 des WHO MONICA-Projektes Augsburg. Aktuel Ernährungsmed 1991; 16: $215-220$

361 Winkler G, Döring A, Keil U. Food intake and nutrient sources in the diet of middle-aged men in Southern Germany: Results from the WHO MONICA Augsburg dietary survey 1984/85. Ann Nutr Metab 1992; 36: $12-22$

362 Winkler G, Döring A, Keil U. Mahlzeitenmuster in einer süddeutschen Bevölkerung: Ergebnisse der Ernährungserhebung 1984/85 des MONICA-Projektes Augsburg. Z Ernährungswiss 1995; 34: 2-9

363 Winkler G, Döring A, Keil U. Meal pattern in middle-aged men in Southern Germany: Results from the MONICA Augsburg Dietary Survey $1984 / 85$. Appetite $1999 ; 32: 33-37$

${ }^{364}$ Winkler G, Döring A, Keil U. Saisonale Schwankungen im Ernährungsverhalten: Ergebnisse der Ernährungserhebung 1984/85 des MONICA Projektes Augsburg. Z Ernährungswiss 1992; 31: 19 - 24

365 Winkler G, Döring A, Keil U. Selected nutrient intakes of middle-aged men in Southern Germany: Results from the WHO MONICA Augsburg Dietary Survey of 1984/85. Ann Nutr Metab 1991; 35: 284-291

${ }^{366}$ Winkler G, Döring A, Keil U. Trends in dietary sources of nutrients among middle-aged men in southern Germany. Results of the MONICA Project Augsburg: dietary surveys 1984/1985 and 1994/1995. Appetite 2000; 34: $37-45$

367 Winkler G, Döring A, Keil U. Unterschiede im Ernährungsverhalten zwischen Wochenenden und Werktagen: Ergebnisse der Ernährungserhebung 1984/85 des MONICA-Projektes Augsburg. Z Ernährungswiss $1991 ; 30: 313-317$

${ }^{368}$ Winkler G, Döring A. Kurzmethoden zur Charakterisierung des Ernährungsmusters: Einsatz und Auswertung eines Food-FrequencyFragebogens. Ernährungs-Umschau 1995; 42: 289-291

369 Winkler G, Döring A. Validation of a short qualitative food frequency list used in several German large scale surveys. Z Ernährungswiss 1998; 37: $234-241$ 
${ }^{370}$ Winkler G, Holtz H, Döring A. Comparison of food intakes of selected populations in former East and West Germany: Results from the MONICA Projects Erfurt and Augsburg. Ann Nutr Metab 1992; 36: 219-234

371 Winkler G, Holtz H, Döring A. Zum Verzehr ausgewählter Lebensmittel in Ost- und Westdeutschland. Ernährungs-Umschau 1992; 39: 200-202

372 Winkler G, Winter A, Döring A. Erfahrungen bei der Kodierung einer Ernährungserhebung mit dem Bundeslebensmittelschlüssel (BLS) 2. Ernährungs-Umschau 1991; 38: 12 - 17

373 Wintermeyer P, Krüger R, Kuhn W, Müller T, Woitalla D, Berg D, Becker G, Leroy E, Polymeropoulos M, Berger K, Pruntek H, Schöls L, Epplen JT, Riess O. Mutation analysis and association studies of the UCHL1 gene in German Parkinson's disease patients. Neuroreport 2000; 11: 2079-2082

${ }^{374}$ Wolf HK, Tuomilehto J, Kuulasmaa K, Domarkiene S, Cepaitis Z, Molarius A, Sans S, Dobson A, Keil U, Rywik S. Blood pressure levels in 41 populations of the WHO MONICA Project. J Hum Hypertens 1997; 11: $733-742$

375 Zhang X, Erdmann J, Regitz-Zagrosek V, Kurzinger S, Hense HW, Schunkert H. Evaluation of three polymorphisms in the promoter region of the angiotensin II type I receptor gene. J Hypertens 2000; 18: $267-272$

376 Zhu X, McKenzie CA, Forrester T, Nickerson DA, Broeckel U, Schunkert H, Doering A, Jacob HJ, Cooper RS, Rieder MJ. Localization of a small genomic region associated with elevated ACE. Am J Hum Genet 2000; 67: $1144-1153$ 